\title{
Checklist of Cambodian bats (Chiroptera), with new records and remarks on taxonomy
}

\begin{abstract}
Vitaliy A. Matveev
ABSTRACT. Thirty-one bat species have been registered in the course of two expeditions to Cambodia in January-February 2000 and July-September 2002. Eight of them, namely Macroglossus sobrinus, Taphozous theobaldi, Hipposideros cineraceus, H. galeritus, Rhinolophus pusillus, Miniopterus schreibersii, Miniopterus sp., and Harpiocephalus harpia are reported from Cambodia for the first time. Occurrence of Rousettus leschenaulti and Pteropus hypomelanus is confirmed, while that of Saccolaimus saccolaimus, on contrary, rejected. Specific distinctiveness of Harpiocephalus mordax has been rejected in the view of the latest findings, including the molecular data. It should be regarded as a synonym of $H$. harpia. One species, Miniopterus sp., is not identified at this stage, and is likely to represent a new species. In general, Cambodian bat fauna could be characterised as typical Indomalayan, with almost $70 \%$ of its registered species not occurring outside the region. It is lacking any species common in the neighbouring zoogeographic regions, with only one, Miniopterus schreibersii, occurring throughout the Old World, Australia, and Oceania. An annotated species list, with notes on taxonomy, distribution and occasionally ecology is presented. Selected measurements have been given as well. Updated checklist with 48 registered bat species is proposed.
\end{abstract}

KEY WORDS: Chiroptera, Cambodia, new records, taxonomy, checklist, Harpiocephalus.

Vitaliy A. Matveev [vital-m@mail.ru], Department of Vertebrate Zoology, Faculty of Biology, Moscow State University, Leninskie Gory, Moscow 119992, Russia.

\section{Перечень видов рукокрылых (Chiroptera) Камбоджи с указанием новых находок и комментариями по таксономии}

\begin{abstract}
B.A. Матвеев
РЕЗЮМЕ. В ходе двух экспедиций в Камбоджу (в январе-феврале 2000 г. и июле-сентябре 2002 г.) собран материал по 31 виду рукокрылых. Восемь из них, а именно Macroglossus sobrinus, Taphozous theobaldi, Hipposideros cineraceus, H. galeritus, Rhinolophus pusillus, Miniopterus schreibersii, Miniopterus sp. и Harpiocephalus harpia отмечены для этой страны впервые. Помимо этого, зарегистрированы два других вида, Rousettus leschenaulti и Pteropus hypomelanus, достоверных сведений по обитанию которых на территории Камбоджи до сих пор не было. Вид Saccolaimus saccolaimus, напротив, исключен из перечня видов рукокрылых страны. Видовая самостоятельность Harpiocephalus mordax опровергнута. Этот таксон следует считать синонимом H. harpia. Один вид длиннокрылов, Miniopterus sp., на настоящий момент определить не удалось. Мы не исключаем, что это новый вид. В целом, фауну рукокрылых Камбоджи можно охарактеризовать как типичную Индомалайскую: около $70 \%$ всех зарегистрированных видов за пределами региона не встречаются, в то время как обычные для соседних зоогеографических областей виды не отмечены. Лишь обыкновенный длиннокрыл (Miniopterus schreibersii) распространен по всему Старому Свету, Австралии и Океании. Приведены развернутые описания отмеченных видов с комментариями по таксономии, распространению и в некоторых случаях — экологии. Представлены таблицы с рядом посткраниальных, краниальных и одонтологических промеров. Приведен обновленный перечень видов рукокрылых Камбоджи из 48 видов.
\end{abstract}

КЛЮЧЕВЫЕ СЛОВА: Chiroptera, Камбоджа, новые находки, таксономия, перечень видов, Harpiocephalus.

\section{Introduction}

Becoming more accessible for foreign researchers nowadays, Cambodia nevertheless still remains one of the least explored countries of Southeast Asia. The same applies to its bat fauna. Compared to Thailand and Vietnam, where bats are relatively well studied,
Cambodia to certain extent still remains a blank spot on the map of Indochina. Moreover, a number of species is artificially 'assigned' to this country as a result of extrapolation of their ranges from adjacent Thailand or Vietnam. A number of recent attempts to get rid of these uncertainties resulted in the series of field investigations (Matveev, 1999; Kock, 2000; Hendrichsen et 


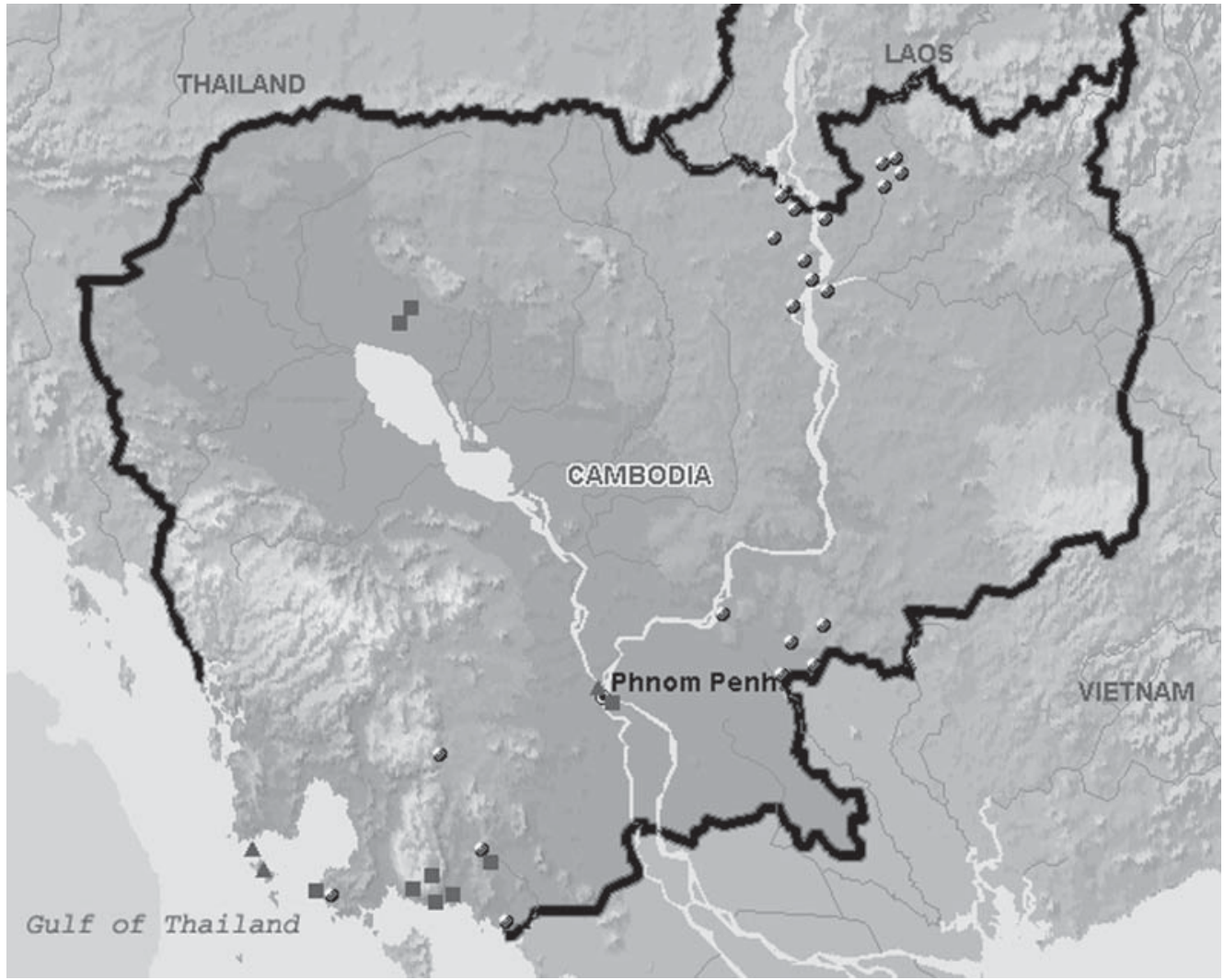

Figure 1. Map of Cambodia with location of author's working sites: triangle - 1998 (Matveev, 1999), square — 2000 (this paper), circle - 2002 (this paper).

al., 2001; Walston \& Bates, 2001) and two consecutive preliminary checklists, which together had shown occurrence of 34 bat species in the country (Kock, 2000; Hendrichsen et al., 2001). All these records, made in Cambodia mainly during the second part of the previous decade, have noticeably filled up the gap in our knowledge of Indochinese bats. At the same time, still much remains to be done.

The present paper is a result of the author's two latest expeditions to the Kingdom of Cambodia, conducted in January-February 2000, and July-September 2002.

Institute abbreviations. BMNH - Natural History Museum, London, Great Britain; ZMMU - Zoological Museum of Moscow State University, Moscow, Russia.

\section{Material and methods}

\section{Studied areas}

The working sites are shown on the map (Fig. 1).

\section{Trapping methods}

Two methods were mainly used to trap bats. The first one, comparatively recently invented (Borissenko, 1999), is based on capturing bats in flight by means of a mobile trap, or so called 'flap-trap'. The device repre- sents a $2.5-3 \mathrm{~m}$ wide and $2 \mathrm{~m}$ long nylon net with $16-18$ $\mathrm{mm}$ mesh stretched between the distal ends of 5-6 m carbon-plastic telescopic rods. It allows trapping bats in flight actively and, when possible, even selectively. The heterodyne bat detector Pettersson D-100 (Uppsala, Sweden) was used simultaneously to detect flying bats. A shorter $4 \mathrm{~m}$ device was used in the forested areas, in a combination with an $80 \mathrm{~W}$ gas-lamp. Secondly, I relied on $7 \mathrm{~m}$ and $12 \mathrm{~m}$ mist-nets, set across the streams, paths and near the cave entrances.

\section{Measurements}

All caught specimens (except for some pteropodids) were weighed with digital scales to the nearest $0.1 \mathrm{~g}(\mathrm{~W})$. The following external measurements were taken to the nearest $0.1 \mathrm{~mm}$ with vernier callipers: $\mathrm{R}$ - forearm length; $\mathrm{C}$ - tail length; $\mathrm{A}$ - ear length; $\mathrm{Cr}$ - tibia length; $\mathrm{Pl}$ - hind foot length excluding claws (Tab. 2). All craniodental measurements (Tab. 3) were taken under dissecting microscope with digital callipers to the nearest $0.01 \mathrm{~mm}$, namely: GL - greatest length of skull; $\mathrm{CBL}$ - condylobasal length; $\mathrm{CC}^{1} \mathrm{~L}-$ condylocanine length; MW - mastoid width; RL — rostral length from preorbital foramen to the alveolus of the inner incisor; RW - rostral width across preorbital foramina; $\mathrm{ZW}$ - zygomatic width; $\mathrm{C}^{1} \mathrm{M}^{\mathrm{n}}$ - length of maxillary toothrow; $\mathrm{C}^{1} \mathrm{C}^{1}-$ external width across upper canines, $\mathrm{M}^{\mathrm{n}} \mathrm{M}^{\mathrm{n}}-$ external width across last upper molars; $\mathrm{C}_{1} \mathrm{M}_{\mathrm{n}}$ - length of mandibular toothrow. 
Table 1. Checklist of Cambodian bats. '+' — registered, '?' — provisional record, ‘-' — rejected.

\begin{tabular}{|c|c|c|c|c|c|}
\hline No & Species & $\begin{array}{l}\text { Matveev } \\
(1999)\end{array}$ & $\begin{array}{l}\text { Kock }(2000) \\
\text { Hendrichsen et al. } \\
(2001) \text { and others }\end{array}$ & $\begin{array}{l}\text { This } \\
\text { paper }\end{array}$ & Notes \\
\hline 1 & Pteropus hypomelanus & $?$ & & + & $\begin{array}{l}\text { The first record for Cambodia for the period of more than } \\
100 \text { years. In Matveev (1999): only sight records on a small } \\
\text { island, adjacent to Kaoh Rung }\end{array}$ \\
\hline 2 & P. lylei & + & & & In Matveev (1999): Phnom Penh \\
\hline 3 & Rousettus leschenaulti & & $?$ & + & Confirmed for Cambodia \\
\hline 4 & R. amplexicaudatus & & + & + & \\
\hline 5 & Cynopterus brachyotis & + & + & + & $\begin{array}{l}\text { In Matveev (1999): Kaoh Rung and adjacent small islands } \\
\text { (the Gulf of Thailand) - the first record for Cambodia }\end{array}$ \\
\hline 6 & C. horsfieldii & & $?$ & & \\
\hline 7 & C. sphinx & + & + & + & \\
\hline 8 & Megaerops ecaudatus & & $?$ & & \\
\hline 9 & M. niphanae & & + & + & \\
\hline 10 & Eonycteris spelaea & & + & + & \\
\hline 11 & Macroglossus minimus & & + & & \\
\hline 12 & M. sobrinus & & & + & The first record for Cambodia \\
\hline 13 & Taphozous melanopogon & + & + & + & \\
\hline 14 & T. longimanus & + & + & + & $\begin{array}{l}\text { In Matveev (1999) was misidentified as Saccolaimus } \\
\text { saccolaimus }\end{array}$ \\
\hline 15 & T. theobaldi & & & + & The first record for Cambodia \\
\hline 16 & Megaderma spasma & $?$ & + & + & \\
\hline 17 & M. lyra & & + & & \\
\hline 18 & Rhinolophus acuminatus & & + & + & \\
\hline 19 & Rh. pusillus & & & + & The first record for Cambodia \\
\hline 20 & Rh. borneensis & & + & + & \\
\hline 21 & Rh. malayanus & & + & + & \\
\hline 22 & Rh. shameli & & + & + & \\
\hline 23 & Rh. luctus & & + & + & \\
\hline 24 & Hipposideros armiger & & + & & \\
\hline 25 & H. cineraceus & & & + & The first record for Cambodia \\
\hline 26 & H. galeritus & & & + & The first record for Cambodia \\
\hline 27 & H. larvatus & + & + & + & \\
\hline 28 & H. pomona & & + & + & \\
\hline 29 & Myotis annectans & & + & & \\
\hline 30 & M. hasseltii & + & + & + & \\
\hline 31 & M. muricola & + & & + & $\begin{array}{l}\text { In Matveev (1999): Phnom Penh — the first record from the } \\
\text { country, confirmed by the voucher specimens }\end{array}$ \\
\hline 32 & M. rosseti & & + & & \\
\hline 33 & Arielulus circumdatus & & + & & \\
\hline 34 & Pipistrellus coromandra & & + & & \\
\hline 35 & P. tenuis & & + & & \\
\hline 36 & Hesperoptenus blanfordi & & + & + & \\
\hline 37 & H. tickelli & & + & + & \\
\hline 38 & Tylonycteris pachypus & & + & & \\
\hline
\end{tabular}


Table 1 (continued).

\begin{tabular}{|c|c|c|c|c|c|}
\hline No & Species & $\begin{array}{l}\text { Matveev } \\
(1999)\end{array}$ & $\begin{array}{c}\text { Kock (2000), } \\
\text { Hendrichsen et al. } \\
(2001) \text { and others }\end{array}$ & $\begin{array}{l}\text { This } \\
\text { paper }\end{array}$ & Notes \\
\hline 39 & T. robustula & & + & & \\
\hline 40 & Miniopterus schreibersii & & & + & The first record for Cambodia \\
\hline 41 & Miniopterus sp. & & & + & Presumably new species \\
\hline 42 & Scotophilus heathi & & + & + & \\
\hline 43 & S. kuhlii & & + & + & \\
\hline 44 & Harpiocephalus harpia & & & + & The first record for Cambodia \\
\hline 45 & Kerivoula hardwickii & & + & & \\
\hline 46 & K. papillosa & & + & & \\
\hline 47 & Chaerephon plicata & + & + & & \\
\hline 48 & Otomops wroughtoni & & + & & Record by Walston \& Bates (2001) \\
\hline \multicolumn{2}{|c|}{ Harpiocephalus mordax } & & & + & Confirmed to be a synonym of $H$. harpia \\
\hline \multicolumn{2}{|c|}{ Saccolaimus saccolaimus } & + & & - & $\begin{array}{l}\text { The only known record for Cambodia (Matveev, 1999) is in } \\
\text { fact misidentified T. longimanus }\end{array}$ \\
\hline
\end{tabular}

Table 2. Selected external measurements of Cambodian bats stored at ZMMU; Pteropus hypomelanus, one specimen of Rousettus leschenaulti, and two Cynopterus sphinx were measured in the field alive; ' $\mathrm{n}$ ' (or figures in parentheses) - the number of measured specimens. Abbreviations are explained in the text.

\begin{tabular}{|c|c|c|c|c|c|c|c|}
\hline Species & $\mathrm{n}$ & $\mathrm{W}$ & $\mathrm{R}$ & $\mathrm{C}$ & A & $\mathrm{Cr}$ & $\mathrm{Pl}$ \\
\hline Pteropus lylei & 3 & - & $137.87 *(1)$ & 0 & $\begin{array}{c}30.46^{*} \\
35.5-37.1\end{array}$ & $61.15^{*}(1)$ & $\begin{array}{c}35.48^{*}, 40.8 \\
\text { (2) }\end{array}$ \\
\hline P. hypomelanus & 1 & - & 138.0 & 0 & 31.0 & 67.0 & 40.6 \\
\hline $\begin{array}{l}\text { Rousettus } \\
\text { amplexicaudatus }\end{array}$ & 2 & $48.5-48.7$ & $69.4-70.0$ & $14.0-14.2$ & $17.4-18.5$ & $27.7-29.5$ & $14.5-16.5$ \\
\hline R. leschenaulti & 2 & $105.0-107.0$ & $82.2-86.5$ & $17.0-17.3$ & $17.4-19.4$ & $36.8-39.2$ & $19.5-20.9$ \\
\hline Cynopterus brachyotis & 10 & $24.5-32.5$ & $58.6-68.6$ & $6.4-16.6$ & $14.5-21.5$ & $21.1-26.3$ & $11.5-14.3$ \\
\hline C. sphinx & 13 & $\begin{array}{c}26.7^{*} \\
35.4-49.8(12)\end{array}$ & $\begin{array}{c}60.0^{*} \\
65.7-70.0(10)\end{array}$ & $\begin{array}{c}8.4^{*}, 6.1-12.7 \\
\text { (9) }\end{array}$ & $\begin{array}{c}16.5^{*} \\
18.1-22.2(9)\end{array}$ & $\begin{array}{c}20.4^{*}, \\
25.0-28.3(9)\end{array}$ & $\begin{array}{c}13.5^{*} \\
12.2-15.6(9)\end{array}$ \\
\hline Megaerops niphanae & 3 & $21.5-23.3$ & $55.6-56.5$ & 0 & $16.0-16.6$ & $21.2-24.2$ & $11.5-13.5$ \\
\hline Eonycteris spelaea & 1 & 40.4 & 66.8 & 15.0 & 19.4 & 29.2 & 16.0 \\
\hline Macroglossus sobrinus & 1 & 28.7 & 46.3 & 0 & 15.4 & 17.3 & 10.8 \\
\hline Taphozous melanopogon & 5 & $20.3-35.1$ & $62.5-67.2$ & $15.5-27.4$ & $17.0-18.4$ & $23.7-25.5$ & $10.0-13.1$ \\
\hline T. longimanus & 3 & $17.6-24.9$ & $56.7-63.0$ & $27.0-30.8$ & $15.7-17.1$ & $24.3-24.8$ & $10.3-12.5$ \\
\hline T. theobaldi & 3 & $26.8-32.7$ & $72.5-74.1$ & $28.7-32.6$ & $22.8-24.0$ & $28.2-28.7$ & $14.5-15.7$ \\
\hline Megaderma spasma & 2 & $11.6-17.7$ & $55.3-55.9$ & 0 & $35.8-37.7$ & $31.2-31.9$ & $13.6-14.0$ \\
\hline Hipposideros cineraceus & 3 & $3.3-4.1$ & $34.8-36.8$ & $24.2-25.9$ & $15.1-16.1$ & $15.2-15.8$ & $5.1-5.8$ \\
\hline H. galeritus & 9 & $6.6-9.1$ & $43.3-50.2$ & $36.4-42.4$ & $13.5-16.0$ & $18.6-21.3$ & $5.4-6.8$ \\
\hline H. pomona & 6 & $5.6-7.1$ & $41.7-44.1$ & $29.2-37.2$ & $19.3-22.5$ & $17.9-20.4$ & $6.4-7.4$ \\
\hline H. larvatus & 27 & $11.5-20.5$ & $57.5-65.9$ & $24.1-37.4$ & $19.6-23.5$ & $21.6-25.1$ & $8.2-11.1$ \\
\hline Rhinolophus acuminatus & 3 & $9.6-13.5$ & $46.8-48.0$ & $21.7-23.6$ & $17.5-17.9$ & $20.0-21.6$ & $9.0-10.9$ \\
\hline Rh. pusillus & 1 & 4.3 & 39.6 & 19.2 & 14.2 & 16.1 & 7.0 \\
\hline Rh. borneensis & 2 & $8.0-10.9$ & $44.5-44.9$ & $19.8-21.0$ & $18.8-20.8$ & $18.9-19.8$ & $7.8-8.7$ \\
\hline Rh. malayanus & 1 & 5.4 & 40.3 & 24.2 & 16.6 & 17.3 & 8.0 \\
\hline Rh. shameli & 4 & $7.8-10.0$ & $46.5-47.4$ & $19.1-20.8$ & $19.0-22.0$ & $21.2-22.9$ & $9.1-9.8$ \\
\hline
\end{tabular}

* Young specimens 
Table 2 (continued).

\begin{tabular}{|l|c|c|c|c|c|c|c|}
\hline Species & $\mathrm{n}$ & $\mathrm{W}$ & $\mathrm{R}$ & $\mathrm{C}$ & $\mathrm{A}$ & $\mathrm{Cr}$ & $\mathrm{Pl}$ \\
\hline Rhinolophus luctus & 1 & 37.3 & 68.7 & 48.5 & 35.9 & 37.3 & 17.0 \\
\hline Myotis hasseltii & 7 & $7.6-9.9(4)$ & $37.5-41.4$ & $38.4-44.2$ & $13.2-15.9$ & $15.6-17.0$ & $9.4-10.3$ \\
\hline M. muricola & 12 & $3.2-5.1$ & $33.1-36.4$ & $35.6-41.3$ & $10.4-12.7$ & $15.0-16.4$ & $5.0-7.0$ \\
\hline $\begin{array}{l}\text { Harpiocephalus harpia } \\
\left(\mathrm{O}^{7}\right)\end{array}$ & 1 & 12.4 & 44.4 & 46.3 & 14.0 & 21.0 & 9.2 \\
\hline H. harpia (+) & 1 & - & 50.2 & - & 14.7 & 23.1 & 10.6 \\
\hline Hesperoptenus blanfordi & 4 & $5.5-8.0$ & $26.6-28.0$ & $27.4-30.2$ & $7.7-8.7$ & $11.2-11.9$ & $4.5-6.6$ \\
\hline H. tickelli & 2 & $13.9-17.8$ & $49.7-53.0$ & $47.8-49.6$ & $14.7-15.0$ & $20.9-22.2$ & $9.5-9.6$ \\
\hline Scotophilus heathi & 1 & 27.8 & 60.5 & 59.2 & 15.6 & 23.4 & 10.7 \\
\hline S. kuhlii & 1 & 22.4 & 50.8 & 49.4 & 13.3 & 19.4 & 9.2 \\
\hline Miniopterus sp. & 3 & $6.5-7.0$ & $41.5-42.0$ & $49.7-57.4$ & $8.3-8.9$ & $17.5-18.1$ & $7.2-8.4$ \\
\hline M. schreibersii & 2 & $8.0-8.1$ & $42.8-43.6$ & $47.9-50.6$ & $9.6-9.7$ & $17.0-17.2$ & $8.5-9.4$ \\
\hline Chaerephon plicata & 11 & $12.0-20.8$ & $47.9-50.8$ & $27.2-47.5$ & $16.9-20.5$ & $15.9-18.1$ & $6.6-11.6$ \\
\hline
\end{tabular}

Table 3. Selected craniodental measurements of Cambodian bats stored at ZMMU; ' $n$ ' (or figures in parentheses) — the number of measured specimens. Abbreviations are explained in the text.

\begin{tabular}{|c|c|c|c|c|c|c|c|c|}
\hline Species & $\mathrm{n}$ & GL & CBL & $\mathrm{CC}^{1} \mathrm{~L}$ & $\mathrm{C}^{1} \mathrm{M}^{\mathrm{n}}$ & $\mathrm{C}^{1} \mathrm{C}^{1}$ & $\mathrm{M}^{\mathrm{n}} \mathrm{M}^{\mathrm{n}}$ & $\mathrm{C}_{1} \mathrm{M}_{\mathrm{n}}$ \\
\hline Pteropus lylei & 1 & $60.07 *$ & $57.50 *$ & $53.25 *$ & $22.29 *$ & $11.36^{*}$ & $14.54 *$ & $24.91 *$ \\
\hline Rousettus leschenaulti & 1 & 40.13 & 38.51 & 36.81 & 14.78 & 8.39 & 11.60 & 16.17 \\
\hline R. amplexicaudatus & 1 & 32.36 & 30.56 & 29.48 & 11.82 & 6.20 & 9.98 & 13.26 \\
\hline Cynopterus brachyotis & 3 & $\begin{array}{c}28.52-29.50 \\
\text { (2) }\end{array}$ & $26.62-28.76$ & $\begin{array}{c}25.92-27.07 \\
\text { (2) }\end{array}$ & $\begin{array}{c}9.42-9.50 \\
\text { (2) }\end{array}$ & $\begin{array}{c}6.05-6.33 \\
(2)\end{array}$ & $\begin{array}{c}8.45-8.54 \\
\text { (2) }\end{array}$ & $\begin{array}{c}10.51-10.52 \\
\text { (2) }\end{array}$ \\
\hline C. sphinx & 2 & $31.74(1)$ & $29.66-30.12$ & $29.52(1)$ & $11.17(1)$ & $7.10(1)$ & $9.43(1)$ & $12.26(1)$ \\
\hline Megaerops niphanae & 1 & 27.42 & 25.81 & 25.68 & 8.50 & 5.28 & 8.36 & 9.33 \\
\hline Macroglossus sobrinus & 1 & 28.89 & 27.27 & 25.49 & 9.89 & 5.72 & 6.87 & 10.97 \\
\hline Eonycteris spelaea & 1 & 32.65 & 30.90 & 29.46 & 12.02 & 6.56 & 8.21 & 13.20 \\
\hline Taphozous melanopogon & 1 & 22.12 & 20.00 & 20.37 & 9.10 & 4.14 & 8.79 & 9.96 \\
\hline T. longimanus & 1 & 21.28 & 19.07 & 19.78 & 9.05 & 3.93 & 8.32 & 9.83 \\
\hline T. theobaldi & 1 & 24.80 & 23.22 & 23.30 & 10.89 & 4.93 & 10.37 & 11.89 \\
\hline Megaderma spasma & 1 & 24.48 & 21.16 & 21.72 & 9.10 & 4.82 & 7.90 & 10.35 \\
\hline Hipposideros cineraceus & 3 & $15.29-15.73$ & $13.22-13.46$ & $13.00-13.32$ & $4.93-5.20$ & $2.88-2.92$ & $4.74-5.00$ & $5.39-5.43$ \\
\hline H. pomona & 3 & $18.00-18.90$ & $15.61-16.36$ & $15.40-16.12$ & $6.20-6.60$ & $3.89-4.04$ & $6.08-6.29$ & $6.69-7.18$ \\
\hline H. galeritus & 3 & $17.26-17.94$ & $14.91-15.23$ & $14.61-14.87$ & $5.52-5.74$ & $3.36-3.54$ & $5.70-5.77$ & $5.87-6.07$ \\
\hline H. larvatus & 6 & $23.80-24.34$ & $20.67-21.24$ & $19.86-20.71$ & $8.90-9.25$ & $5.46-6.02$ & $8.77-9.23$ & $9.55-10.02$ \\
\hline Rhinolophus acuminatus & 1 & 21.14 & 17.97 & 17.78 & 7.79 & 5.22 & 8.17 & 8.51 \\
\hline Rh. pusillus & 1 & 16.75 & 14.42 & 14.08 & 6.10 & 3.95 & 6.33 & 6.61 \\
\hline Rh. borneensis & 2 & $20.16-20.60$ & $17.63-18.06$ & $16.91-17.79$ & $7.46-7.74$ & $4.91-5.02$ & $7.23-7.51$ & $7.86-8.42$ \\
\hline Rh. malayanus & 1 & 18.20 & 15.70 & 15.47 & 6.90 & 4.46 & 6.76 & 7.51 \\
\hline Rh. shameli & 1 & 21.72 & 19.18 & 18.43 & 8.20 & 5.45 & 7.61 & 8.67 \\
\hline Rh. luctus & 1 & 31.22 & 27.13 & 26.79 & 11.51 & 7.83 & 10.73 & 12.71 \\
\hline Myotis hasseltii & 2 & $15.91-16.09$ & $14.71-14.87$ & $13.99-14.16$ & $5.79-5.83$ & $4.53-4.66$ & 6.26 & $6.28-6.31$ \\
\hline M. muricola & 2 & $13.72-13.75$ & $12.76-12.88$ & $12.10-12.13$ & $5.09-5.23$ & $3.48-3.64$ & $5.52-5.59$ & $5.44-5.59$ \\
\hline
\end{tabular}

* Young specimens 
Table 3 (continued).

\begin{tabular}{|l|c|c|c|c|c|c|c|c|}
\hline Species & $\mathrm{n}$ & $\mathrm{GL}$ & $\mathrm{CBL}$ & $\mathrm{CC}^{1} \mathrm{~L}$ & $\mathrm{C}^{1} \mathrm{M}^{\mathrm{n}}$ & $\mathrm{C}^{1} \mathrm{C}^{1}$ & $\mathrm{M}^{\mathrm{n}} \mathrm{M}^{\mathrm{n}}$ & $\mathrm{C}_{1} \mathrm{M}_{\mathrm{n}}$ \\
\hline Harpiocephalus harpia $\left(\mathrm{O}^{7}\right)$ & 1 & 21.24 & 19.12 & 18.61 & $6.55\left(\mathrm{C}^{1} \mathrm{M}^{2}\right)$ & 6.35 & 7.04 & 7.62 \\
\hline H. harpia $(+))$ & 1 & 23.32 & 20.88 & 20.38 & $7.17\left(\mathrm{C}^{1} \mathrm{M}^{2}\right)$ & 7.11 & $7.66\left(\mathrm{M}^{2} \mathrm{M}^{2}\right)$ & 8.37 \\
\hline Hesperoptenus blanfordi & 2 & $12.78-13.13$ & $11.84-11.86$ & $11.97-12.18$ & $4.20-4.32$ & $4.23-4.36$ & $5.84-6.36$ & $4.59-4.72$ \\
\hline H. tickelli & 1 & 18.24 & 17.26 & 17.63 & 7.22 & 6.40 & 8.99 & 8.06 \\
\hline Scotophilus heathi & 1 & 22.26 & 19.66 & 20.07 & 7.22 & 7.00 & 9.40 & 8.21 \\
\hline S. kuhlii & 1 & 20.13 & 17.74 & 18.06 & 6.51 & 6.53 & 8.48 & 7.38 \\
\hline Miniopterus sp. & 3 & $\begin{array}{c}14.51-14.59 \\
(2)\end{array}$ & $\begin{array}{c}13.46-13.57 \\
(2)\end{array}$ & $\begin{array}{c}12.69-12.75 \\
(2)\end{array}$ & $5.37-5.41$ & $4.07-4.23$ & $5.57-5.80$ & $\begin{array}{c}5.71-5.77 \\
(2)\end{array}$ \\
\hline M. schreibersii & 2 & $15.53-15.88$ & $14.68-14.79$ & $13.88-13.94$ & $6.09-6.19$ & $4.71-4.69$ & $6.37-6.47$ & $6.47-6.54$ \\
\hline Chaerephon plicata & 2 & $20.25-20.52$ & $18.28-18.70$ & $17.53-17.82$ & $7.43-7.73$ & $5.27-5.30$ & $8.78-8.95$ & 8.23 \\
\hline
\end{tabular}

\section{Results}

Pteropus hypomelanus Temminck, 1853 Fig. 2.

Material. One adult male was trapped by the locals at the end of 2001, presumably on one of the small islets in the Gulf of Thailand (the area of Kâmpóng Saôm Bay). Since then it has been remaining in captivity. The bat was measured and photographed, the tissue samples were taken for the genetic analysis.

Remarks on taxonomy and distribution. This species demonstrates strong adherence to small islands and is not known from the mainland. The above individual, caught by Kâmpóng Saôm locals, is likely to originate from one of those few islands in the bay known for being inhabited by flying foxes (Matveev, 1999).

This species was reported to occur in Cambodia by Andersen (1912), with reference to Dobson (1880: 173) and Trouessart (1897: 82). However, no other records appear in the later publications. This species was also listed for Cambodia by Lord Medway (1978) and in the IUCN/SSC Action Plan for Conservation of Old World Fruit Bats (Mickleburgh et al., 1992) with no indication of the exact locality or any reference given. It was also not included into the latest species checklist by Kock (2000), presumably on the reason that this fruit-bat had not been reported for the country over the past century. Therefore, the present record is the first for the period of more than 100 years, confirming the presence of $P$. hypomelanus in Cambodia.

Andersen (1912) included this country into the range of the subspecies P. h. condorensis Peters, 1869. Indeed, the observed specimen could be characterised with the features, 'typical' of this form: mixed sealbrown and silvery grey back, somewhat hazel chest and belly, and blackish chestnut mantle, as well as short, more or less rounded ear (Fig. 2). The forearm is 138 $\mathrm{mm}$ (Tab. 2), which is very close to that of the type specimen (135 mm; Andersen, 1912), and is within the appropriate dimensions of several $P . h$. condorensis, stored in the BMNH collection (ca. 132-142 mm).

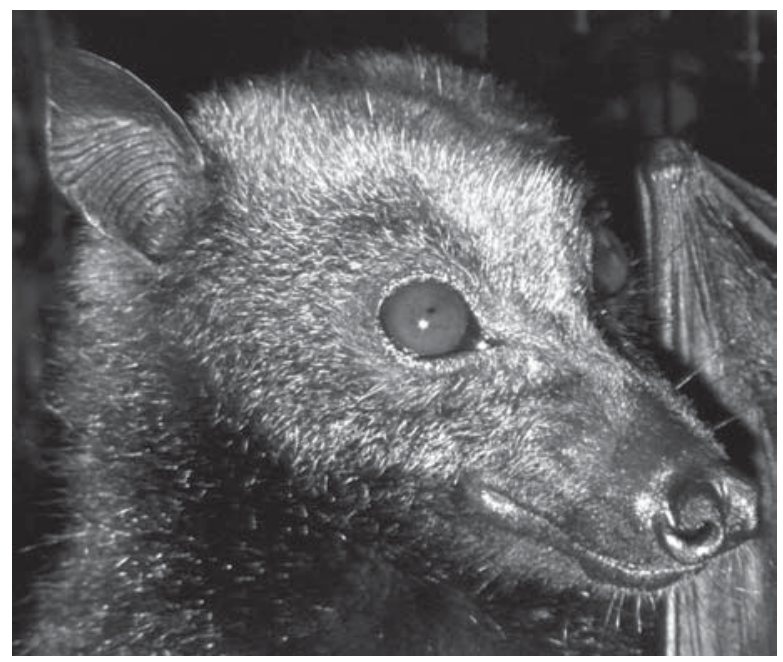

Figure 2. Captive male of Pteropus hypomelanus.

Rousettus (Rousettus) leschenaulti (Desmarest, 1820) Fig. 3.

Material. Phnom Sila caves, 20-25 km northeast of Kâmpôt, Kâmpôt Province $\left(10^{\circ} 46^{\prime} \mathrm{N}, 104^{\circ} 19^{\prime} \mathrm{E}\right), 30$ January 2000, one adult male was photographed and released after external measurements and the samples of wing-membrane had been taken for DNA analysis; 11 August 2002, one adult male (ZMMU S-174743).

Remarks on taxonomy and distribution. This is the first authentic record of the species for Cambodia, which previously was mapped, but listed with a question mark for this country by Corbet \& Hill (1992).

It has widely been accepted, that the most reliable diagnostic feature allowing to distinguish between $R$. leschenaulti and $R$. amplexicaudatus is the narrower last lower molar of the former, versus more or less rounded in the latter (Andersen, 1912; Corbet \& Hill, 1992; Koopman, 1994). Indeed, in the caught specimens $M_{3}$ was almost twice as long as wide. At the same time, our measurements clearly demonstrate that these two species significantly differ in size and weight, with $R$. leschenaulti being conspicuously larger and two times heavier (Tabs. 2 and 3). 


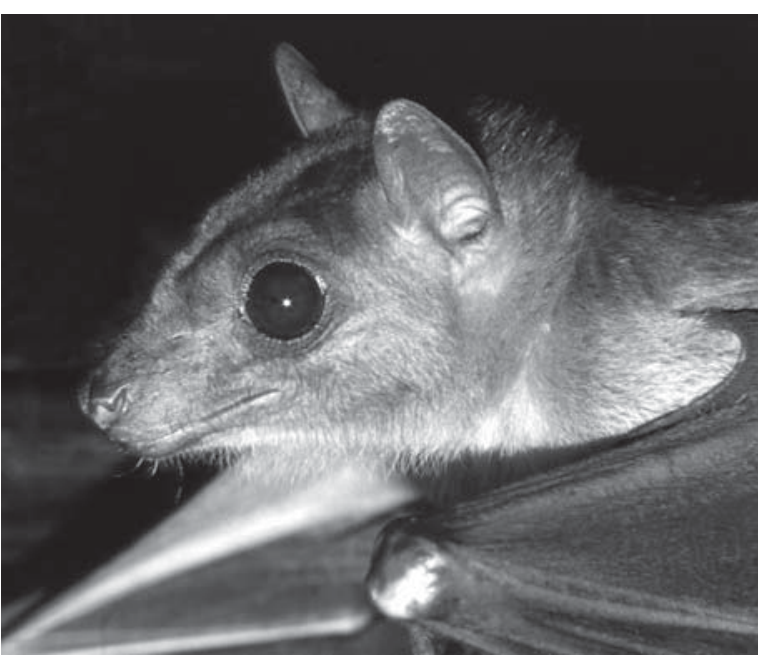

Figure 3. Male Rousettus leschenaulti (ZMMU S-174743), Kâmpôt Province.

Since Rookmaaker \& Bergmans (1981) tentatively identified this species in Angkor Wat (north-western Cambodia) this country is listed (though with a question-mark) as a part of the species' range (Corbet \& Hill, 1992; Kock, 2000), while the present record proves its occurrence in Cambodia.

Cambodian representatives of $R$. leschenaulti are characterised with pilose nape and forearm and hence should be assigned to the nominate subspecies, $R$. $l$. leschenaulti (Desmarest, 1820), occupying the mainland part of the species' range (Corbet \& Hill, 1992; Koopman, 1994).

Ecological remarks. The above specimens were caught in the colony of ca. 120-130 individuals, sharing the same karst cave with several species of the genera Hipposideros, Rhinolophus, and Taphozous.

Rousettus (Rousettus) amplexicaudatus (Geoffroy, 1810) Fig. 4.

Material. Phnom Chngouck cave, $5 \mathrm{~km}$ northwest of Phumı̌ Khsan, Stŭng Trêng Province $\left(13^{\circ} 45^{\prime} \mathrm{N}, 105^{\circ} 45^{\prime} \mathrm{E}\right), 1$ September 2002, one adult male, one adult female (ZMMU S174741 and S-174742).

Remarks on taxonomy and distribution. The captured Cambodian specimens have subcircular posterior lower molars, characteristic of this species. However, their size is noticeably smaller (Tabs. 2 and 3), than reported for this species (Andersen, 1912; our data). In the only Cambodian specimen, stored at the BMNH (7.1.1.263), the forearm is conspicuously longer too: $77 \mathrm{~mm}$ (versus 69.4-70 $\mathrm{mm}$ ).

Subspecific affiliation of Cambodian representatives needs further investigation, though the mainland populations (e.g. from Thailand and Malay Peninsula) are usually referred to the nominate form (Koopman, 1994).

Ecological remarks. A colony of several hundred individuals was found with another cave dweller, Eonycteris spelaea (see below), inside the large cave in the karst formation.

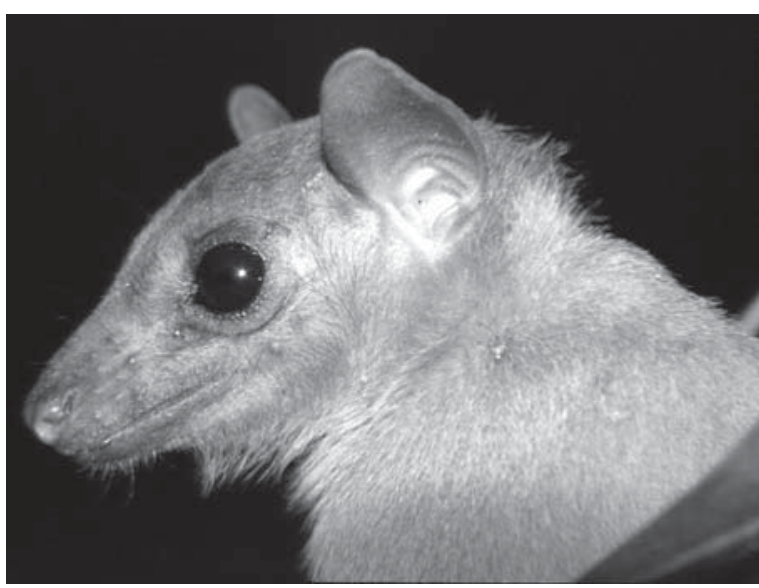

Figure 4. Female Rousettus amplexicaudatus (ZMMU S174742), Stŭng Trêng Province.

\section{Cynopterus brachyotis (Müller, 1838)}

Fig. 5.

Material. Southern extremity of the Elephant Mountains, Kâmpôt Province $\left(10^{\circ} 42^{\prime}-10^{\circ} 35^{\prime} \mathrm{N}, 104^{\circ} 00^{\prime}-104^{\circ} 08^{\prime} \mathrm{E}\right), 29$ January 2000, one adult male, two adult females (ZMMU S168322 - S-168324). $100 \mathrm{~km}$ southwest of Phnom Penh, Kâmpóng Speu Province $\left(11^{\circ} 18^{\prime} \mathrm{N}, 104^{\circ} 02^{\prime} \mathrm{E}\right), 29$ July 2002, one adult female (ZMMU S-174698). Vicinities of Kâmpóng Saôm, Krŏng Preăh Sihanouk Province, 26 July 2002, one adult male (ZMMU S-174699).

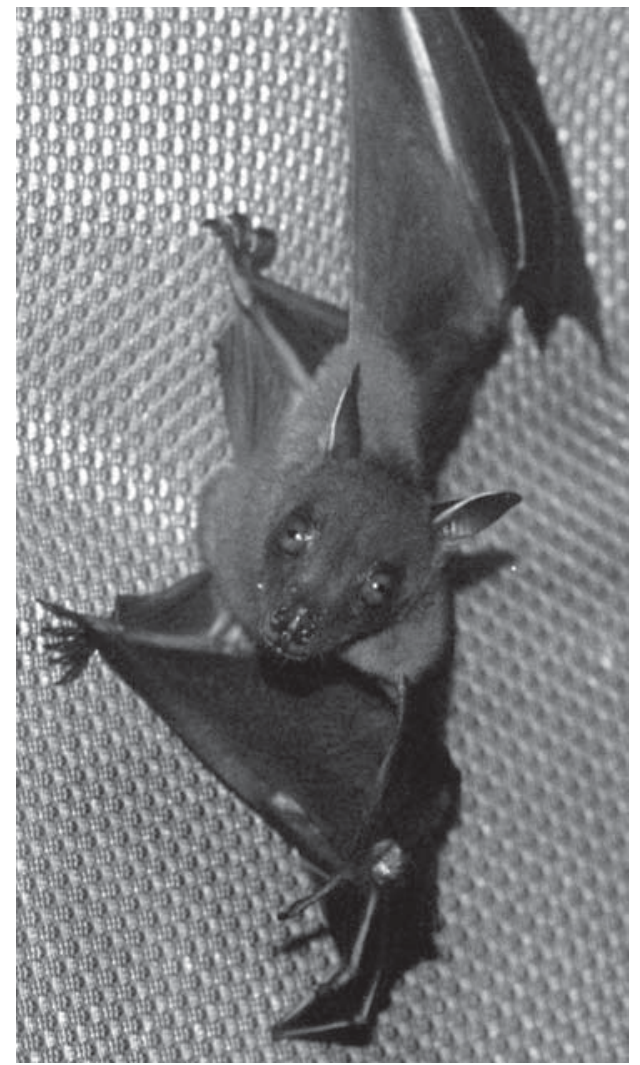

Figure 5. Male Cynopterus brachyotis (ZMMU S-166146), Kaôh Rŭng Island, the Gulf of Thailand. 


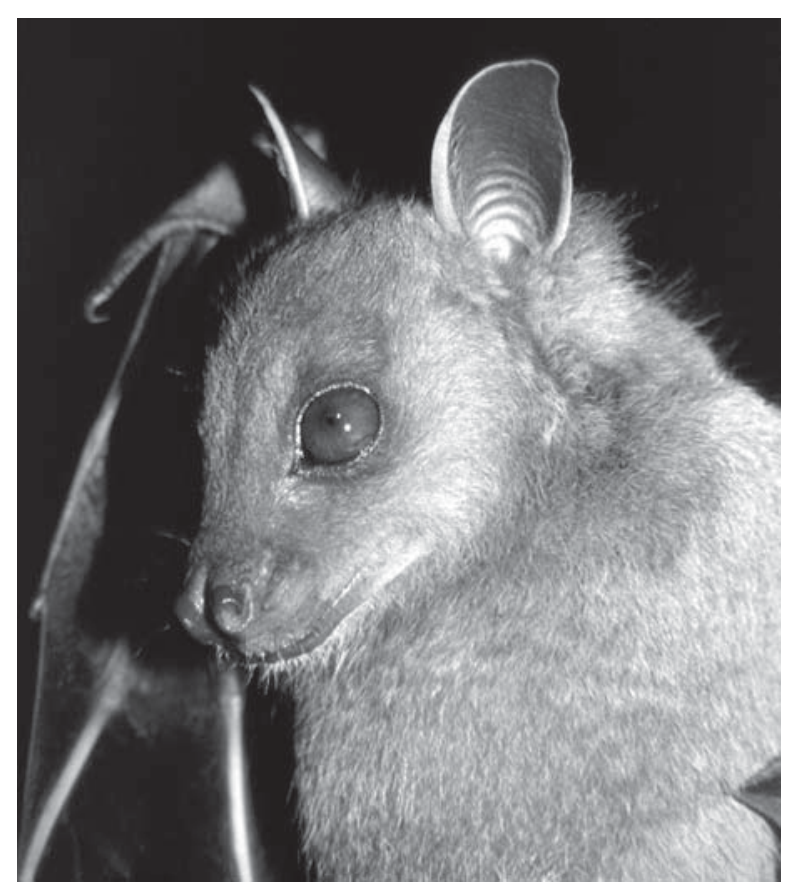

Figure 6. Male Cynopterus sphinx (ZMMU S-174700), Stŭng Trêng Province.

Remarks on taxonomy and distribution. This species was first mapped (but not listed) for Cambodia by Corbett \& Hill (1992), while the first voucher specimens were collected by Matveev (1999) on several islands (including Kaôh Rŭng) off Cambodia's coast. Later it was also recorded by Hendrichsen et al. (2001).

There appears to be no morphological criterion, neither external, nor craniodental, by which C. brachyotis could be readily distinguished from C. sphinx, rather than relatively shorter ears in the former: a feature yet mentioned by Andersen (1912). From this point a further search for the reliable diagnostic features is quite topical. Hill \& Thonglongya (1972) suggested separating C. brachyotis and C. sphinx, overlapping by forearm and ear lengths, by the combination of these two parameters. However, the ear length appears to be not convenient enough for such a purpose, as the ways different researchers take this measurement may vary.

However, in spite of the above similarities, there appears to be one parameter, allowing separating the two sibling species quite readily: it is weight (Tab. 2). The same conclusion was made by S.V. Kruskop (ZMMU), who studied Vietnamese representatives of both species (pers. comm.). This parameter even works on bats of similar size.

Cynopterus archipelagus (Philippines) and C. minor (Sulawesi), first mistakenly recognised by Hill (1983) as two distinct species, were later included in $C$. brachyotis: each was described from a single immature specimen of C. b. brachyotis (Müller, 1838) (Heaney et al., 1987 and Bergmans \& Rozendaal, 1988, respectively; also see Koopman, 1989; Corbet \& Hill, 1992; Mickleburgh et al., 1992). The mainland populations (except those from Malayan highlands) are usually referred to the nominate subspecies (Koopman, 1994).

\section{Cynopterus sphinx (Vahl, 1798)}

Fig. 6.

Material. Southern extremity of the Elephant Mountains, Kâmpôt Province $\left(10^{\circ} 42^{\prime}-10^{\circ} 35^{\prime}\right.$ N, $104^{\circ} 00^{\prime}-104^{\circ} 08^{\prime}$ E), 29 January 2000, one adult male (ZMMU S-168325); 10 February 2000, one adult male (ZMMU S-168326). Siěmpang and the vicinities, Stŭng Trêng Province $\left(14^{\circ} 06^{\prime}-14^{\circ} 07^{\prime} \mathrm{N}, 106^{\circ} 16^{\prime}-\right.$ $106^{\circ} 23^{\prime}$ E), 26 August 2002, one young male (ZMMU S174702). Phumì Dân Loŭng, Stŭng Trêng Province $\left(14^{\circ} 02^{\prime} \mathrm{N}\right.$, $106^{\circ} 20^{\prime} \mathrm{E}$ ), 26 August 2002, two adult males (ZMMU S-174700 and S-174701).

Remarks on taxonomy and distribution. The subspecific structure of $C$. sphinx and C. brachiotis represents certain difficulties, with some forms even being shuffled between these taxa. However, based primarily on the cranial measurements (Tab. 3), the Cambodian specimens could undoubtedly be allocated as $C$. $s$. angulatus Miller, 1908 (also see Andersen (1912) for measurements, who treated this taxon as the largest form of C. brachyotis).

\section{Megaerops niphanae Yenbutra \& Felten, 1983} Fig. 7.

Material. Southern extremity of the Elephant Mountains, Kâmpôt Province $\left(10^{\circ} 42^{\prime}-10^{\circ} 35^{\prime}\right.$ N, $104^{\circ} 00^{\prime}-104^{\circ} 08^{\prime}$ E), 28 January 2000, one adult male (ZMMU S-168327); 10 February 2000 , one adult male, one adult female pregnant with one foetus (ZMMU S-168328 and S-168329).

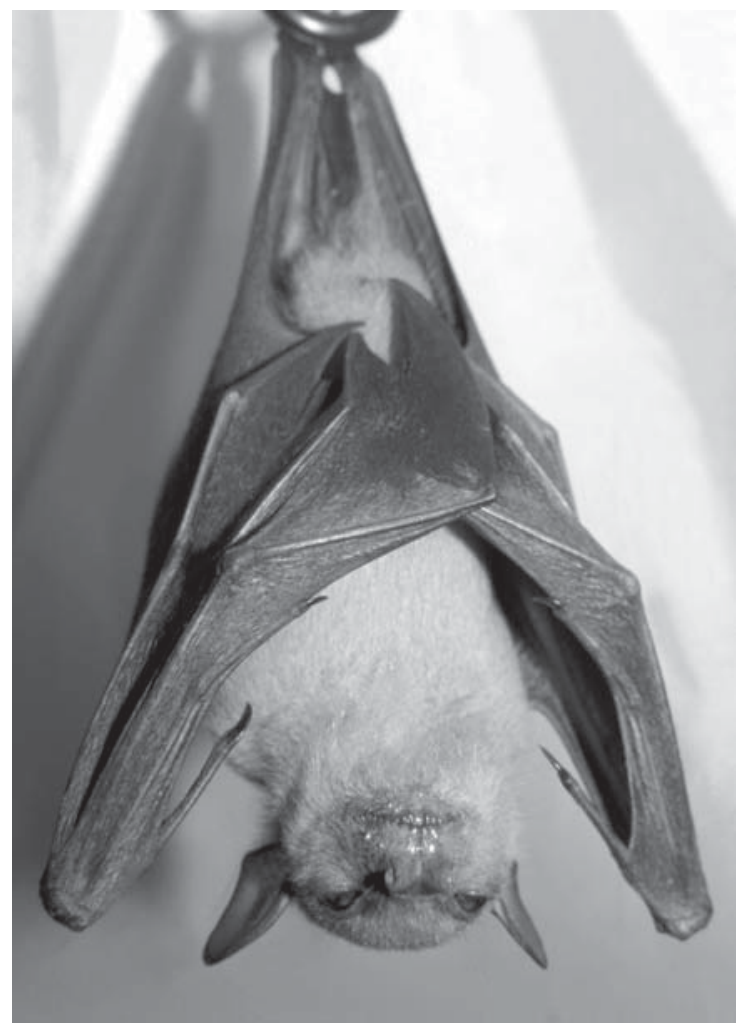

Figure 7. Male Megaerops niphanae (ZMMU S-168328), Kâmpôt Province. 


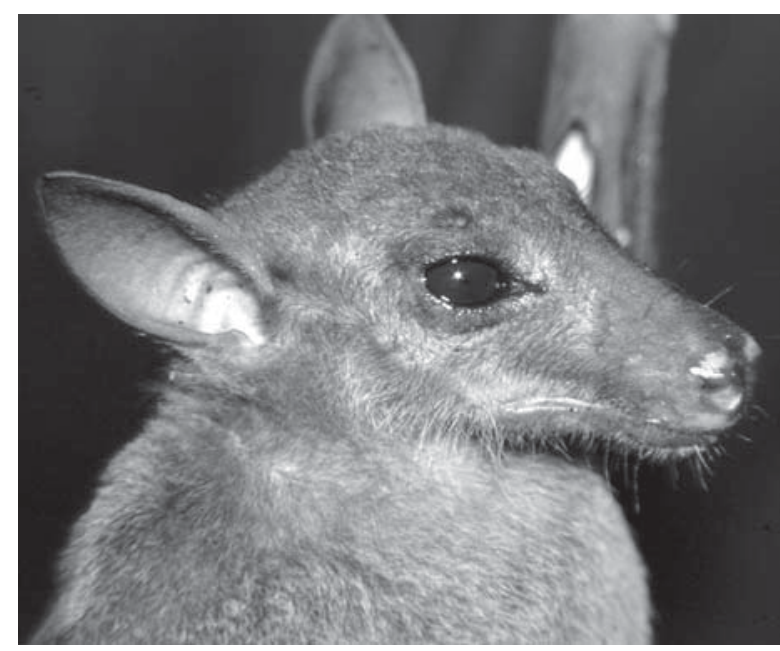

Figure 8. Male Eonycteris spelaea (ZMMU S-174703), Stŭng Trêng Province.

Remarks on taxonomy and distribution. Kock (2000) assumes M. ecaudatus, reported from Popork Village Forest (Klein, 1971), may pertain to M. niphanae, which had not been distinguished by that time. Therefore, Klein's finding could be the first record of M. niphanae for Cambodia. No subspecies.

\section{Eonycteris spelaea (Dobson, 1871)}

\section{Fig. 8.}

Material. Phnom Chngouck cave, $5 \mathrm{~km}$ northwest of

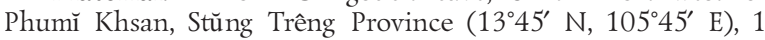
September 2002, one adult male (ZMMU S-174703).

Remarks on taxonomy and distribution. Subspecies are poorly defined.

Macroglossus sobrinus Andersen, 1911

$$
\text { Fig. } 9 .
$$

Material. Southern extremity of the Elephant Mountains Kâmpôt Province $\left(10^{\circ} 42^{\prime}-10^{\circ} 35^{\prime} \mathrm{N}, 104^{\circ} 00^{\prime}-104^{\circ} 08^{\prime} \mathrm{E}\right), 31$ January 2000, one adult female (ZMMU S-168322).

Remarks on taxonomy and distribution. This is the first record of this species for Cambodia. Corbet \& Hill (1992) mapped but not listed it for this country.

Most of the species range, excluding the Mentawais, is occupied by the nominate subspecies (Corbet \& Hill, 1992; Koopman, 1994).

Taphozous melanopogon Temminck, 1841 Fig. 10.

Material. Southern extremity of the Elephant Mountains, Kâmpôt Province $\left(10^{\circ} 42^{\prime}-10^{\circ} 35^{\prime} \mathrm{N}, 104^{\circ} 00^{\prime}-104^{\circ} 08^{\prime} \mathrm{E}\right), 25$ January 2000, one adult male (ZMMU S-168330). Southern extremity of the Elephant Mountains, Kâmpôt Province $\left(10^{\circ} 42^{\prime}\right.$ $-10^{\circ} 35^{\prime} \mathrm{N}, 104^{\circ} 00^{\prime}-104^{\circ} 08^{\prime} \mathrm{E}$ ), 30 January 2000, one adult female, pregnant with a single embryo (ZMMU S-168332). Phnom Chngouck cave, eastward of Kâmpôt, Kâmpôt Province, 30 January 2000, one adult male (ZMMU S-168331).

Remarks on taxonomy and distribution. Ellerman \& Morrison-Scott (1951) treated T. m. bicolor

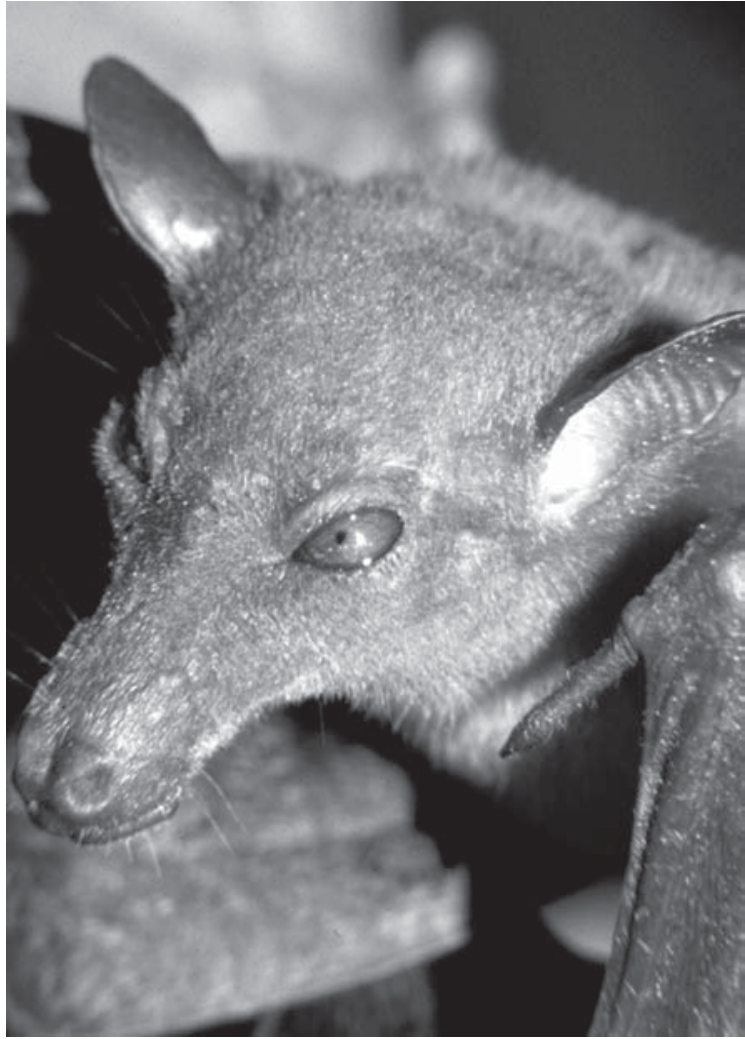

Figure 9. Male Macroglossus sobrinus (ZMMU S-168339), Kâmpôt Province.

Temminck, 1841 as a synonym of the nominate subspecies, but Koopman (1994) accepted it as additional subspecies, inhabiting India and Sri Lanka east to southern China and Vietnam, including the Andaman Islands. Following this view, Cambodian specimens should pertain to bicolor. However, Bates \& Harrison (1997) do not consider it distinct even at subspecific level, due to considerable variation in size and colour in this species.

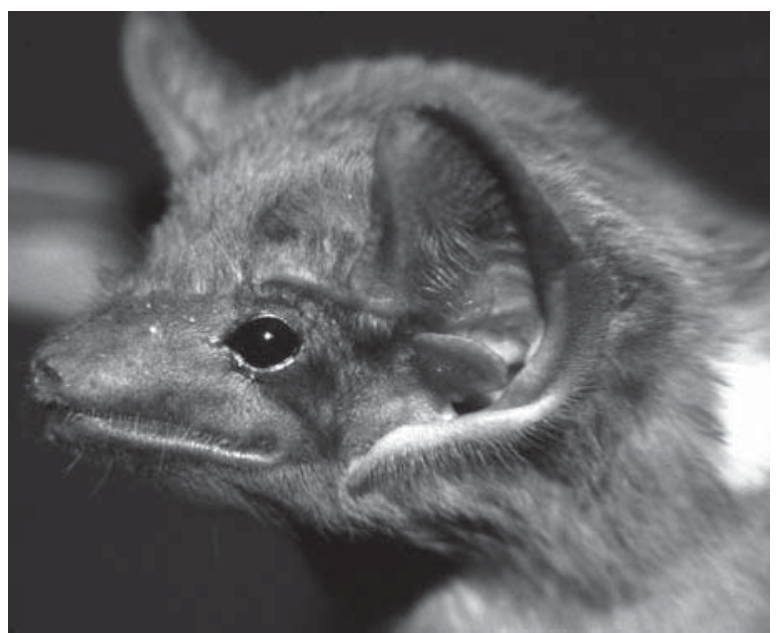

Figure 10. Male Taphozous melanopogon (ZMMU S168330), Kâmpôt Province. 


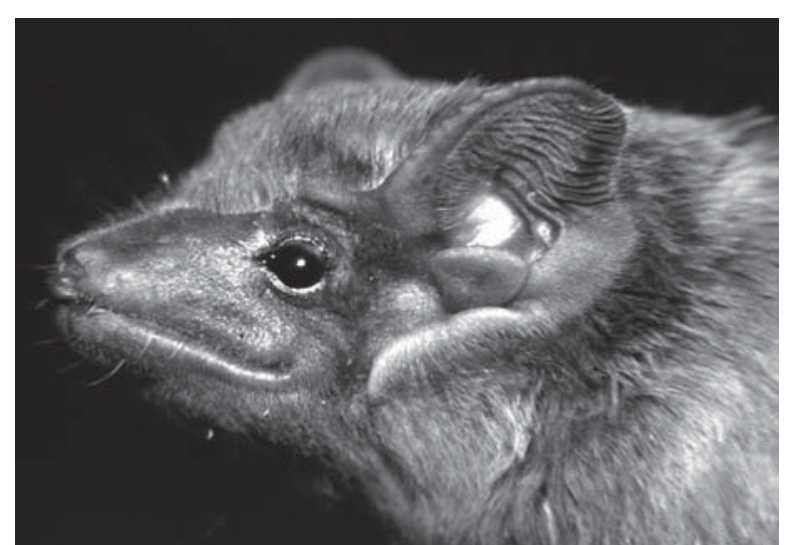

Figure 11. Male Taphozous longimanus (ZMMU S-168304), Phnom Penh.

Taphozous longimanus Hardwicke, 1825

Fig. 11.

Material. The city of Phnom Penh, 21 January 2000, two adult males (ZMMU S-166149 and S-168304). Ponhea Kraêk,

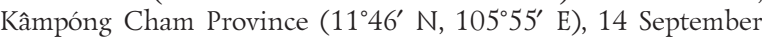
2002, one adult male (ZMMU S-174748).

Remarks on taxonomy and distribution. Cambodian specimens belong to the nominate subspecies $T$. $l$. longimanus Hardwicke, 1825, occurring as far to the west as India and Sri Lanka.

The only known record of Saccolaimus saccolaimus (Temminck, 1838) from Cambodia (Matveev, 1999) is misidentified T. longimanus. Nonetheless, recent surveys by A.V. Borissenko in Vietnam (Borissenko \& Kruskop, 2003) showed occurrence of this species literally $5 \mathrm{~km}$ away from Cambodian border $\left(11^{\circ} 37^{\prime} \mathrm{N}\right.$, $105^{\circ} 53^{\prime} \mathrm{E}$ ), on a narrow projection of Vietnamese territory into that of Cambodia. These records from Vietnam (the voucher specimens are deposited at the ZMMU) demonstrate that this species is rather probable to occur in Cambodia as well. However, the au- thor's survey in the region gave no result. Meanwhile, $S$. saccolaimus should be excluded from the list of Cambodian bats.

\section{Taphozous theobaldi Dobson, 1872}

Fig. 12.

Material. Phnom Chngouck cave, $5 \mathrm{~km}$ northwest of Phumı̌ Khsan, Stŭng Trêng Province $\left(13^{\circ} 45^{\prime} \mathrm{N}, 105^{\circ} 45^{\prime} \mathrm{E}\right), 1$ September 2002, one adult male, two adult females (ZMMU S174749 - S-174751).

Remarks on taxonomy and distribution. This is the first record of $T$. theobaldi for Cambodia. The majority of the species' range, including Indochina, is occupied by the nominate subspecies (e.g. Koopman, 1994), which could be readily distinguished from T. $t$. secatus Thomas, 1915 by the throat patch of darker brown hairs present in older males (Khajuria, 1979).

Megaderma (Megaderma) spasma (Linnaeus, 1758) Fig. 13.

Material. Vicinities of Kâmpóng Saôm, Krŏng Preăh Sihanouk Province, 27 July 2002, one adult male (ZMMU S174718). Siěmpang and the vicinities, Stŭng Trêng Province $\left(14^{\circ} 06^{\prime}-14^{\circ} 07^{\prime} \mathrm{N}, 106^{\circ} 16^{\prime}-106^{\circ} 23^{\prime} \mathrm{E}\right), 25$ August 2002, one adult female (ZMMU S-174719).

Remarks on taxonomy and distribution. Cambodian representatives belong to the form M. s. minus Andersen, 1918 (Andersen, 1918; Shamel, 1942; Corbet \& Hill, 1992; Koopman, 1994), which has distinctly smaller size than in many other subspecies, with forearm ranging from 53.5 to $56.5 \mathrm{~mm}$ (Phillips, 1967; also see Tab. 2).

\section{Hipposideros galeritus Cantor, 1846}

Fig. 14.

Material. Southern extremity of the Elephant Mountains, Kâmpôt Province $\left(10^{\circ} 42^{\prime}-10^{\circ} 35^{\prime} \mathrm{N}, 104^{\circ} 00^{\prime}-104^{\circ} 08^{\prime} \mathrm{E}\right), 24-$ 31 January 2000, 01-07 February 2000, two adult males, six

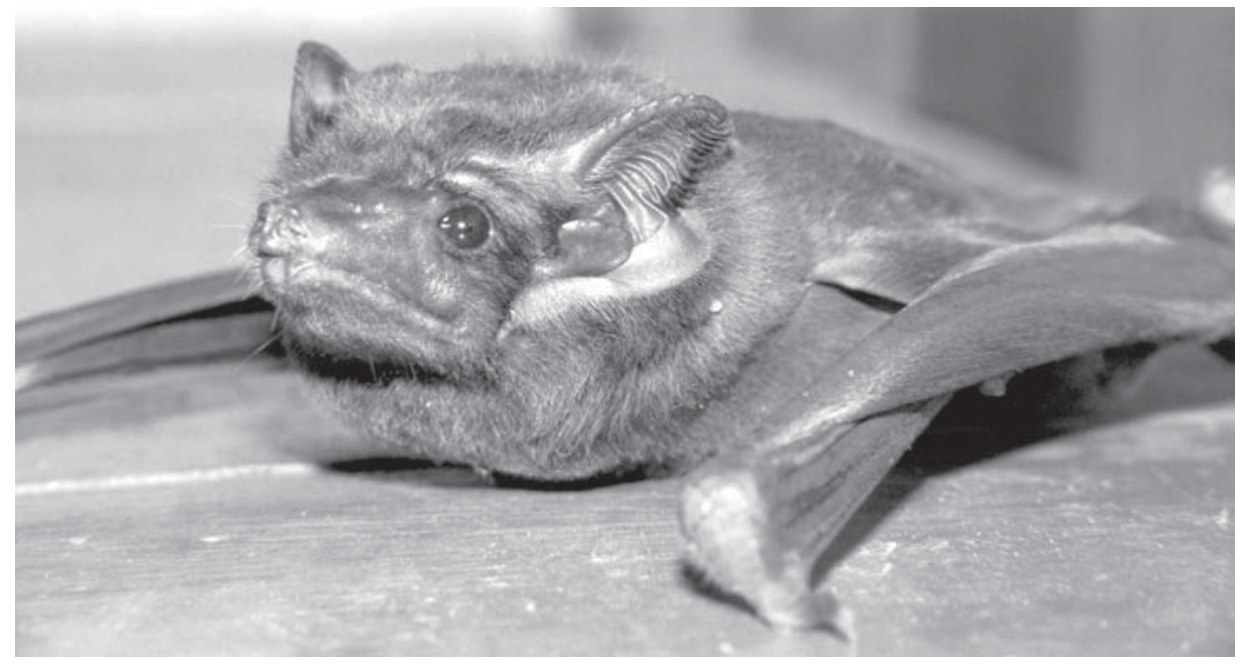

Figure 12. Male Taphozous theobaldi (ZMMU S-174750), Stŭng Trêng Province. 


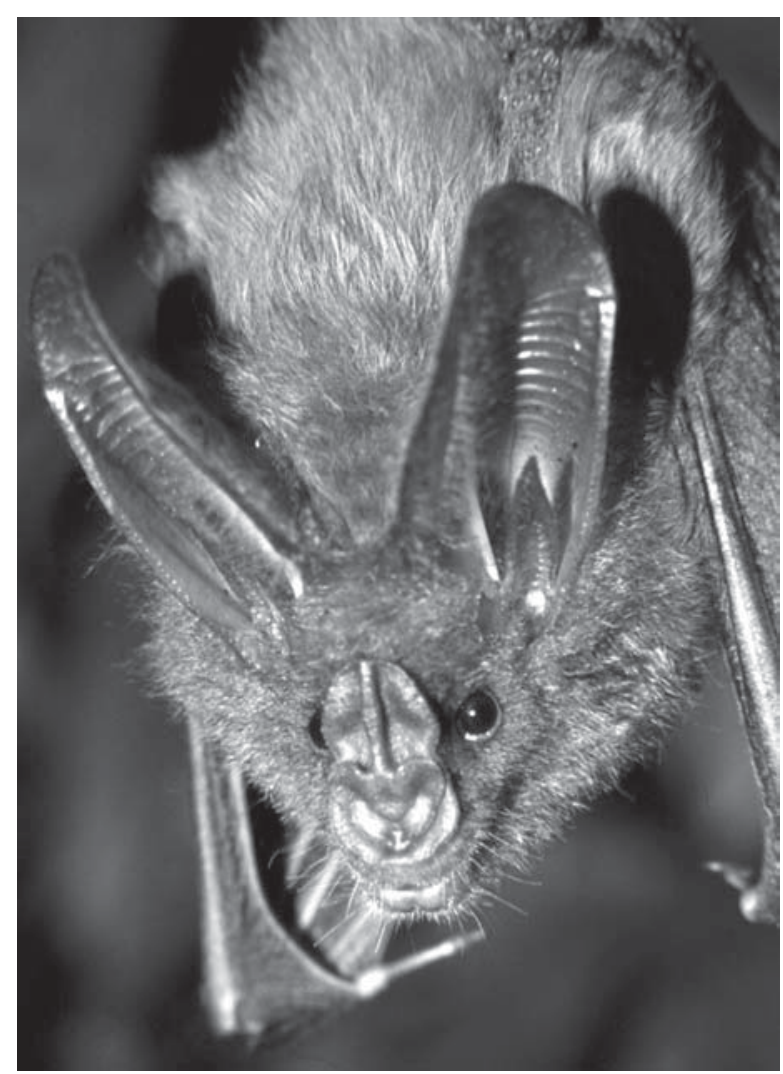

Figure 13. Male Megaderma spasma (ZMMU S-174718), Krŏng Preăh Sihanouk Province.

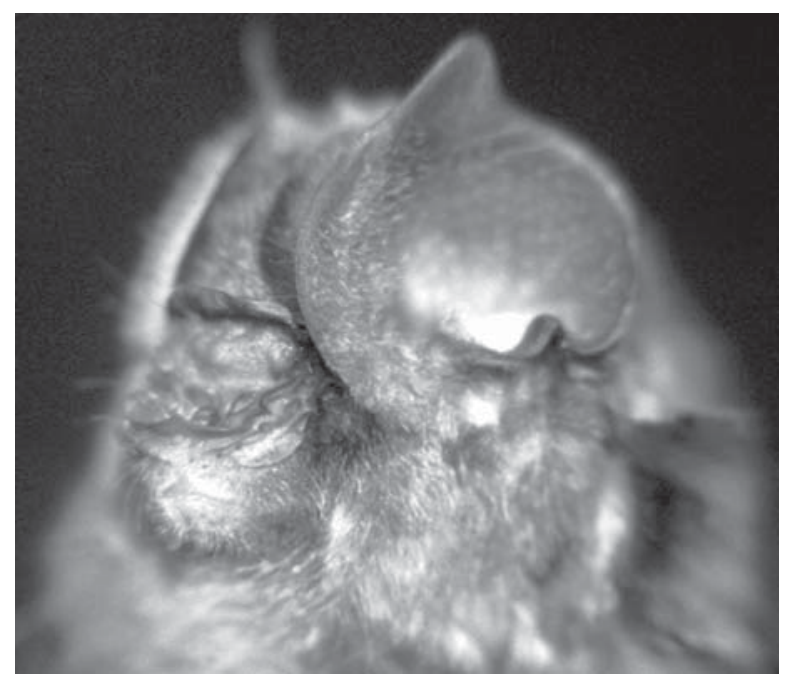

Figure 14. Hipposideros galeritus, Kâmpôt Province.

adult females, five of which were pregnant with a single embryo (ZMMU S-168314 - S-168321). Phnom Sila caves, 20-25 km northeast of Kâmpôt, Kâmpôt Province (1046' N, 104 19' E), 11 August 2002, one adult female (ZMMU S-174711).

Remarks on taxonomy and distribution. This is the first record of this species for Cambodia. Hitherto it has been reported for Indochina from the southern provinces of Vietnam only (Huynh et al., 1994), though Koopman (1989) mentioned this species to occur in

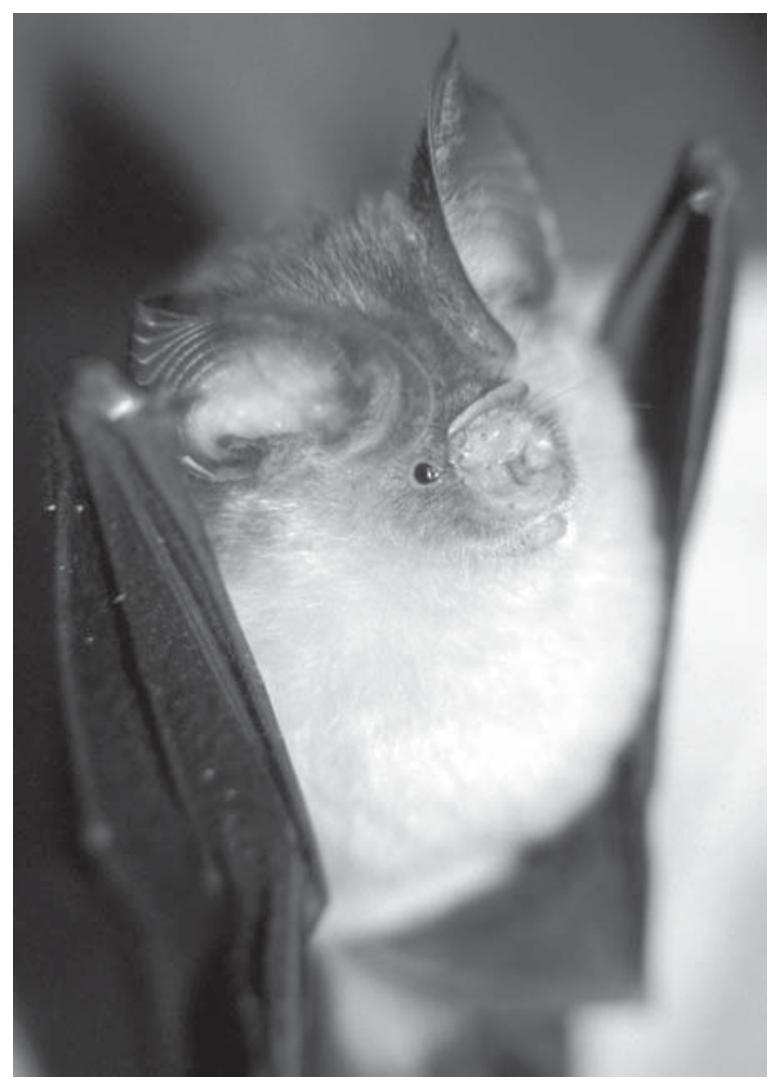

Figure 15. Female Hipposideros cineraceus (ZMMU S174706), Krŏng Preăh Sihanouk Province.

Indochina in some limited part of Thailand, but neither gave the exact locality, nor the reference. Four subspecies are currently recognised (Corbet \& Hill, 1992; Koopman, 1994). The allocation of Indochinese specimens requires further investigation.

\section{Hipposideros cineraceus Blyth, 1853}

Fig. 15.

Material. Southern extremity of the Elephant Mountains, Kâmpôt Province $\left(10^{\circ} 42^{\prime}-10^{\circ} 35^{\prime} \mathrm{N}, 104^{\circ} 00^{\prime}-104^{\circ} 08^{\prime} \mathrm{E}\right), 24$ January 2000, one adult male (ZMMU S-168310). Vicinities of Kâmpóng Saôm, Krŏng Preăh Sihanouk Province, 7 August 2002, one adult female (ZMMU S-174706). Phnom Chngouck cave, $5 \mathrm{~km}$ northwest of Phumǐ Khsan, Stŭng Trêng Province $\left(13^{\circ} 45^{\prime} \mathrm{N}, 105^{\circ} 45^{\prime} \mathrm{E}\right), 1$ September 2002 , one adult male (ZMMU S-174710).

Remarks on taxonomy and distribution. This is the first record of $H$. cineraceus for Cambodia, being the southernmost point of its distribution in Indochina. The largest part of the species' range, excluding southern India and the Philippines, is occupied by the nominate subspecies (Hill \& Francis, 1984).

\section{Hipposideros pomona Andersen, 1918}

Fig. 16.

Material. Southern extremity of the Elephant Mountains, Kâmpôt Province $\left(10^{\circ} 42^{\prime}-10^{\circ} 35^{\prime}\right.$ N, $104^{\circ} 00^{\prime}-104^{\circ} 08^{\prime}$ E), 2425 January 2000, three adult males (ZMMU S-168311 - S- 


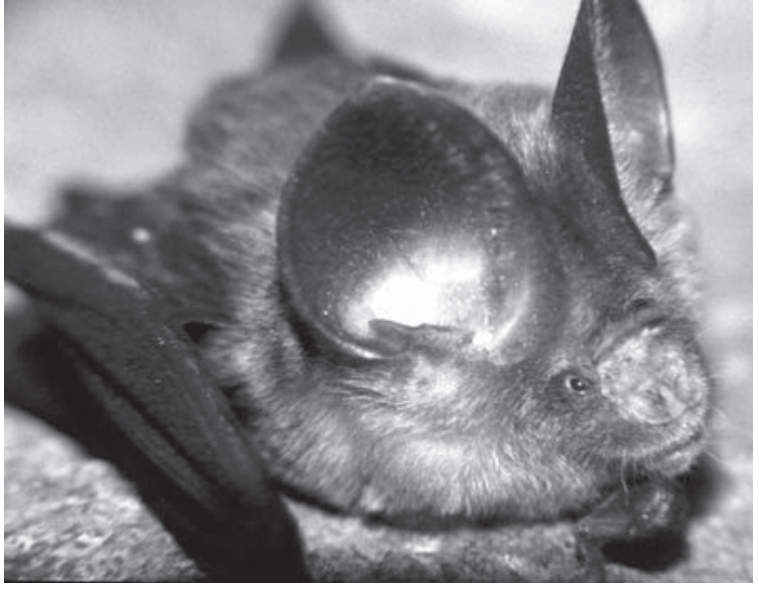

Figure 16. Male Hipposideros pomona (ZMMU S-168312), Kâmpôt Province.

168313). Phnom Chngouck cave, $5 \mathrm{~km}$ northwest of Phumi Khsan, Stŭng Trêng Province $\left(13^{\circ} 45^{\prime} \mathrm{N}, 105^{\circ} 45^{\prime} \mathrm{E}\right), 1$ September 2002, three adult males (ZMMU S-174707 - S-174709).

Remarks on taxonomy and distribution. Three subspecies are usually recognised (Hill et al., 1986). Cambodian specimens should be referred to the form sinensis: they are conspicuously larger than the nominate form and gentilis (Tabs. 2 and 3), the jugal projection is lacking, while the anterior lower premolar is very large.

Hipposideros larvatus (Horsfield, 1823)

Fig. 17.

Material. Research site 4, 30 January 2000, four adult males (ZMMU S-168306-S-168309). Phnom Loang cave, 30 $\mathrm{km}$ east of Kâmpôt, Kâmpôt Province (10 $27^{\prime}$ N, 104 $25^{\prime}$ E), 10 August 2002, one adult male, one adult female (ZMMU S174712 and S-174713). $3 \mathrm{~km}$ southeast of Phumî Kâmpóng Sœãmeu, Preãh Vihéar Province $\left(13^{\circ} 57^{\prime} \mathrm{N}, 105^{\circ} 52^{\prime} \mathrm{E}\right), 6$ September 2002, three adult males, one adult female (ZMMU S-174714-S-174717)

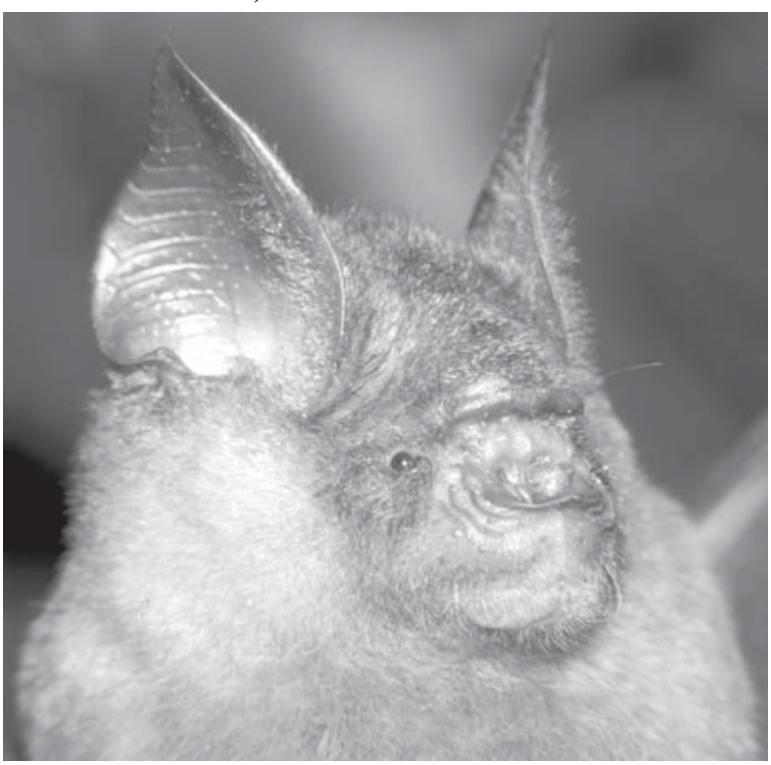

Figure 17. Male Hipposideros larvatus (ZMMU S-174713), Kâmpôt Province.

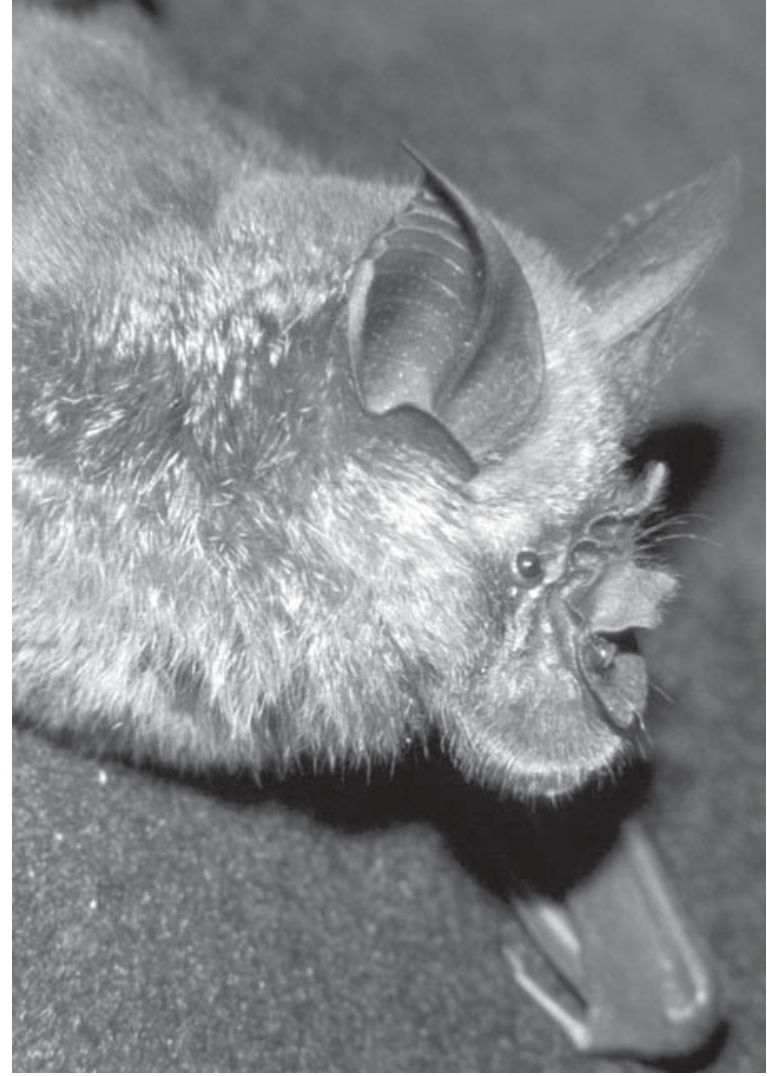

Figure 18. Female Rhinolophus acuminatus (ZMMU S174735), Stŭng Trêng Province.

Remarks on taxonomy and distribution. As per Corbet \& Hill (1992), Vietnamese specimens pertain to H. l. alongensis Bourret, 1942, whereas Koopman (1994) listed it only for the north of the country, while those from the south he referred to the form grandis. Individuals caught in Vietnam by S.V. Kruskop (ZMMU) are of the same size with those from the south of Cambodia (except for one specimen from Kebang, Quan Binh Province, Vietnam, with the length of the forearm as short as $51.9 \mathrm{~mm}$ ), in which forearm ranges from 57.5 to $63.4 \mathrm{~mm}$ (and only in one is as long as 65.9 $\mathrm{mm}$; Tab. 2), coinciding with the data from Myanmar: 57.5-63.0 mm (Bates et al., 2000), inhabited by H. $l$. grandis Allen, 1936. These data agree with other records of H. l. grandis G.M. Allen, 1936 from Cambodia (Klein, 1969, 1971), and confirm the view, that Cambodian populations pertain to the form grandis.

Rhinolophus acuminatus Peters, 1871 Fig. 18.

Material. 2 km westwards of Phumĭ Krăng Cham, Stŭng Trêng Province $\left(13^{\circ} 26^{\prime} \mathrm{N}, 105^{\circ} 51^{\prime} \mathrm{E}\right), 30$ August 2002, one adult male (ZMMU S-174733). Siěmpang and the vicinities, Stŭng Trêng Province $\left(14^{\circ} 06^{\prime}-14^{\circ} 07^{\prime} \mathrm{N}, 106^{\circ} 16^{\prime}-106^{\circ} 23^{\prime} \mathrm{E}\right)$, 28 August 2002, two adult females (ZMMU S-174734 and S174735).

Remarks on taxonomy and distribution. Five subspecies are currently recognised. However, the subspe- 


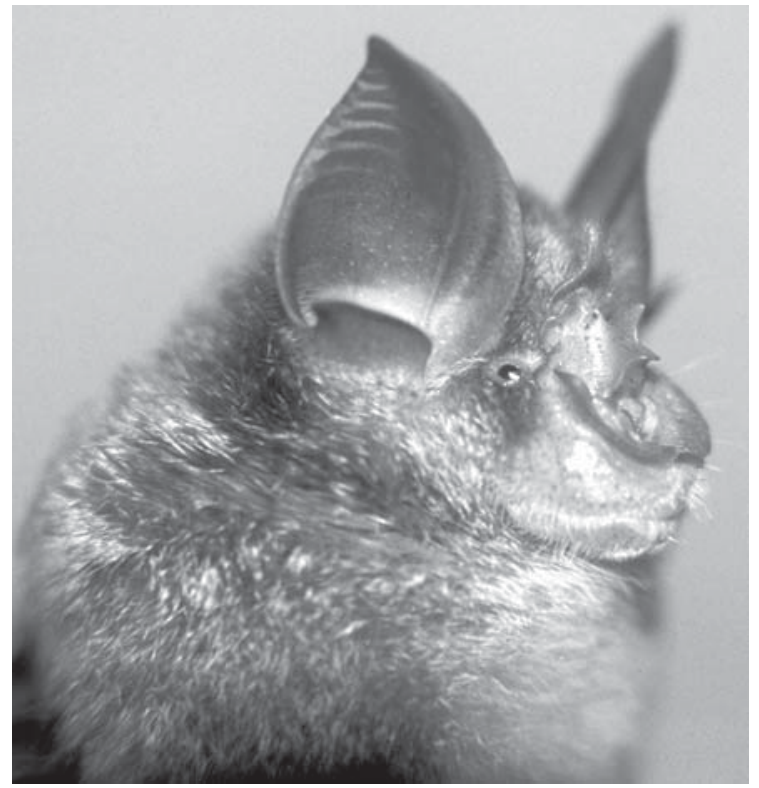

Figure 19. Female Rhinolophus pusillus (ZMMU S-174736), Kâmpóng Speu Province.

cific allocation of mainland populations is uncertain and requires special investigations. In general, mainland specimens resemble those from Java (the nominate form) and Lombok, inhabited by audax (Koopman, 1994; Csorba et al., 2003).

\section{Rhinolophus pusillus Temminck, 1834}

Fig. 19.

Material. $100 \mathrm{~km}$ southwest of Phnom Penh, Kâmpóng Speu Province $\left(11^{\circ} 18^{\prime} \mathrm{N}, 104^{\circ} 02^{\prime}\right.$ E), 29 July 2002 , one adult female (ZMMU S-174736).

Remarks on taxonomy and distribution. The first record for Cambodia. This country was mapped, but not listed as a part of this species' range by Corbet \& Hill (1992). Subspecific allocation of Cambodian population needs further investigations. The adjacent parts of the known species' range are occupied by szechuanus (including Thailand), calidus (including Vietnam) and minutillus (including Malay Peninsula) (Koopman, 1994).

\section{Rhinolophus borneensis Peters, 1861}

Fig. 20.

Material. Prey Houng Waterfalls, $25 \mathrm{~km}$ north of Phum-

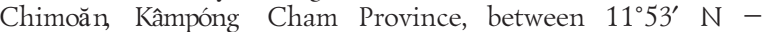
$11^{\circ} 56^{\prime} \mathrm{N}, 105^{\circ} 57^{\prime} \mathrm{E}$ and $11^{\circ} 53^{\prime} \mathrm{N}-11^{\circ} 56^{\prime} \mathrm{N}, 106^{\circ} 01^{\prime} \mathrm{E}, 15$ September 2002, two adult males (ZMMU S-174731 and S174732).

Remarks on taxonomy and distribution. In the captured specimens the male is conspicuously larger than the female. Cambodian representatives are referred to Rh. b. chaseni Sanborn, 1939 (Hill \& Thonglongya, 1972; Koopman, 1994). The present record is the easternmost in the country.

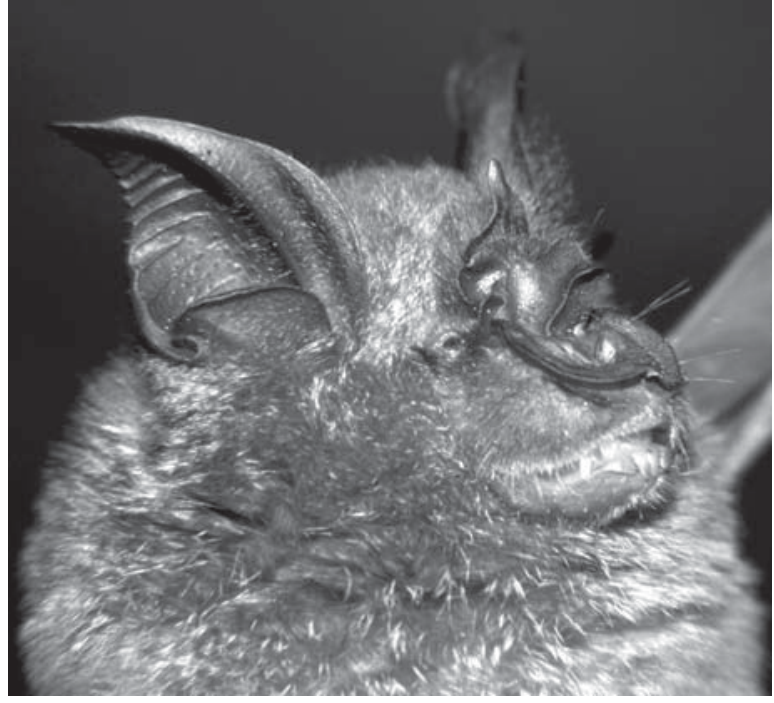

Figure 20. Male Rhinolophus borneensis (ZMMU S-174731), Kâmpóng Cham Province.

Rhinolophus malayanus Bonhote, 1903

Fig. 21.

Material. Phnom Sila caves, 20-25 km northeast of Kâmpôt, Kâmpôt Province $\left(10^{\circ} 46^{\prime} \mathrm{N}, 104^{\circ} 19^{\prime} \mathrm{E}\right), 11$ August 2002, one adult male (ZMMU S-174730).

Remarks on taxonomy and distribution. The position of the second lower premolar in the toothrow may vary from slightly extruded to external (Csorba et al., 2003). In this particular specimen it is extruded, but not external: $\mathrm{P}_{2}$ and $\mathrm{P}_{4}$ are not in contact. This species has no subspecies.

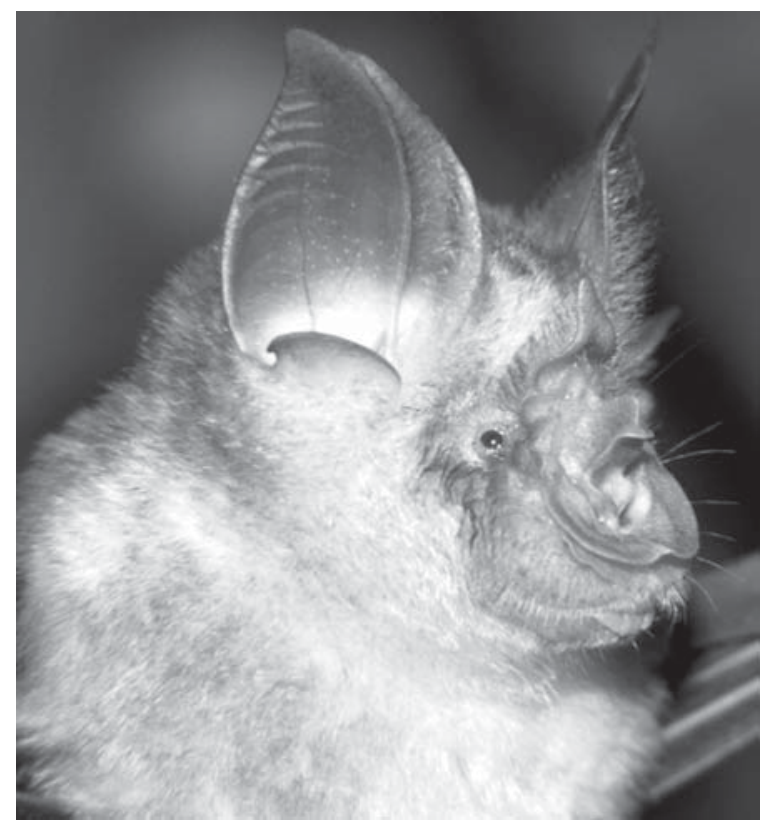

Figure 21. Male Rhinolophus malayanus (ZMMU S-174730), Kâmpôt Province. 


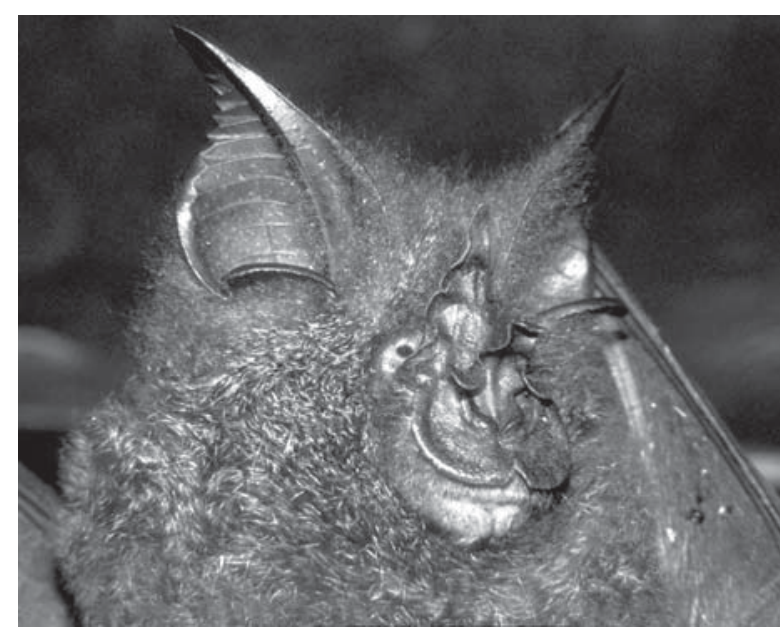

Figure 22. Female Rhinolophus luctus (ZMMU S-174737), Kâmpóng Cham Province.

\section{Rhinolophus luctus Temminck, 1834}

Fig. 22.

Material. Prey Houng Waterfalls, $25 \mathrm{~km}$ north of PhumChimoăn, Kâmpüng Cham Province, roughly between $11^{\circ} 53^{\prime} \mathrm{N}$ $-11^{\circ} 56^{\prime} \mathrm{N}, 105^{\circ} 57^{\prime} \mathrm{E}$ and $11^{\circ} 53^{\prime} \mathrm{N}-11^{\circ} 56^{\prime} \mathrm{N}, 106^{\circ} 01^{\prime} \mathrm{E}, 15$ September 2002, one adult female (ZMMU S-174737).

Remarks on taxonomy and distribution. This is the second record of this species from Cambodia. Apart from the above individual, and the first record by Hendrichsen et al. (2001), another specimen was visually observed and photographed by O. Shumakov in Phnom Bokor National Park, southern Cambodia. Therefore, this species is now known for the Cardamom Mountains in the south-west, for the east of the country (close to Vietnamese border), and for the Elephant Mountains in the south.

Hendrichsen et al. (2001) indicated that their specimen from the Cardamom Mountains was similar to $R h$. beddomei (southern India and Sri Lanka). However, the two forms of the latter, namely beddomei and sobrinus, are more commonly treated as subspecies of Rh. luctus (e.g. Corbet \& Hill, 1992; Koopman, 1994). The authors mentioned, that their Cambodian specimen had comparatively smaller size (R $63.1 \mathrm{~mm}, \mathrm{CBL} 26.3 \mathrm{~mm}$, $\mathrm{C}^{1} \mathrm{M}^{\mathrm{n}} 10.6 \mathrm{~mm}$ ), than that of $R$. luctus (i.e. than other forms, apart from beddomei and sobrinus), though still possessed some features, "more typical of Rh. luctus", such as the well developed hollow above the interorbital region.

Our specimen from eastern Cambodia is larger, than the one from the Cardamom Mountains (Tabs. 2 and 3), though still could be treated as average, or even small of its kind. In many parameters it resembles Vietnamese specimens stored at ZMMU (Borissenko \& Kruskop, 2003), and apparently represents the same form. However, the subspecific allocation of Indochinese populations requires further investigation. Individuals from the nearest known localities belong to the following subspecies (Koopman, 1994): perniger (possibly including Thailand) and morio (including Malay Peninsula).

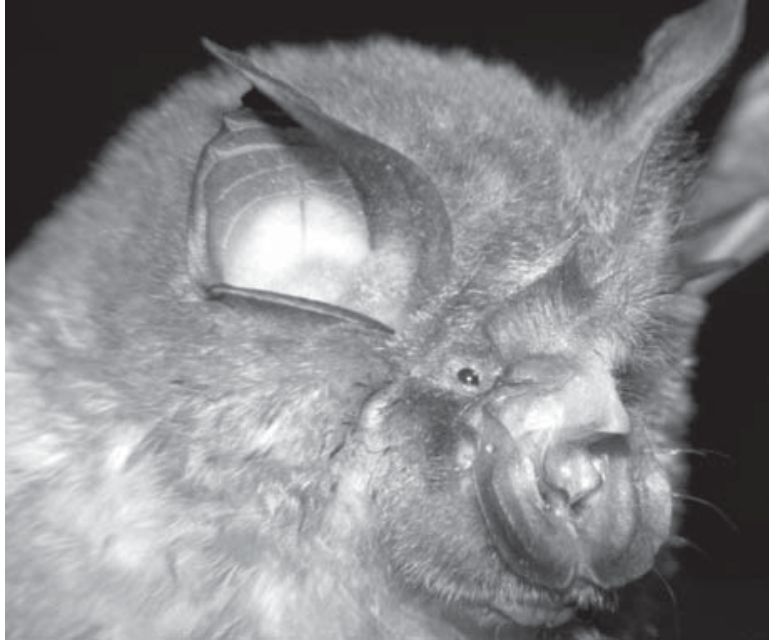

Figure 23. Male Rhinolophus shameli (ZMMU S-174738), Kâmpôt Province.

Rhinolophus shameli Tate, 1943

Fig. 23.

Material. Southern extremity of the Elephant Mountains, Kâmpôt Province $\left(10^{\circ} 42^{\prime}-10^{\circ} 35^{\prime}\right.$ N, $104^{\circ} 00^{\prime}-104^{\circ} 08^{\prime}$ E), 6 February 2000, one adult female (ZMMU S-168305). Phnom Sila caves, 20-25 km northeast of Kâmpôt, Kâmpôt Province $\left(10^{\circ} 46^{\prime} \mathrm{N}, 104^{\circ} 19^{\prime} \mathrm{E}\right), 11$ August 2002, one adult male (ZMMU S-174738). Phnom Chngouck cave, $5 \mathrm{~km}$ northwest of Phumi Khsan, Stŭng Trêng Province $\left(13^{\circ} 45^{\prime}\right.$ N, $105^{\circ} 45^{\prime}$ E), 1 September 2002, one adult male (ZMMU S-174739). $6 \mathrm{~km}$ west of Preăh Ângkoăl, Stŭng Trêng Province $\left(13^{\circ} 53^{\prime}\right.$ N, 105 54' E), 6 September 2002, one adult female (ZMMU S-174740).

Remarks on taxonomy and distribution. The species appears to be quite common and widespread in Cambodia. No subspecies.

Myotis (Leuconoe) hasseltii Temminck, 1849 Fig. 24

Material. Vicinities of Kâmpóng Saôm, Krŏng Preăh Sihanouk Province, 26 July 2002, two adult males (ZMMU S174722 and S-174723). Stŭng Trêng, Stŭng Trêng Province, 19 August 2002, two adult females (ZMMU S-174724 and S174725).

Remarks on taxonomy and distribution. Hill (1983) recognised four subspecies, with continentis occurring from Myanmar to Cambodia. Earlier it was known as M. adversus continentis Shamel, 1942 (Hill \& Thonglongya, 1972).

Myotis (Selysius) muricola (Gray, 1846) Fig. 25.

Material. Southern extremity of the Elephant Mountains, Kâmpôt Province $\left(10^{\circ} 42^{\prime}-10^{\circ} 35^{\prime} \mathrm{N}, 104^{\circ} 00^{\prime}-104^{\circ} 08^{\prime} \mathrm{E}\right), 4$ February 2000, three adult males and one female pregnant with a single foetus (ZMMU S-168335-S-168338). Vicinities of Kâmpóng Saôm, Krŏng Preăh Sihanouk Province, 26 July 2002, two adult females, including one post-lactating (ZMMU S174726 and S-174727); 5 August 2002, one adult male (ZMMU S-174728). Phumǐ Kâmpóng Sœãmeu, Preãh Vihéar Province $\left(13^{\circ} 58^{\prime} \mathrm{N}, 105^{\circ} 51^{\prime} \mathrm{E}\right), 5$ September 2002 , one adult male (ZMMU S-174729). 


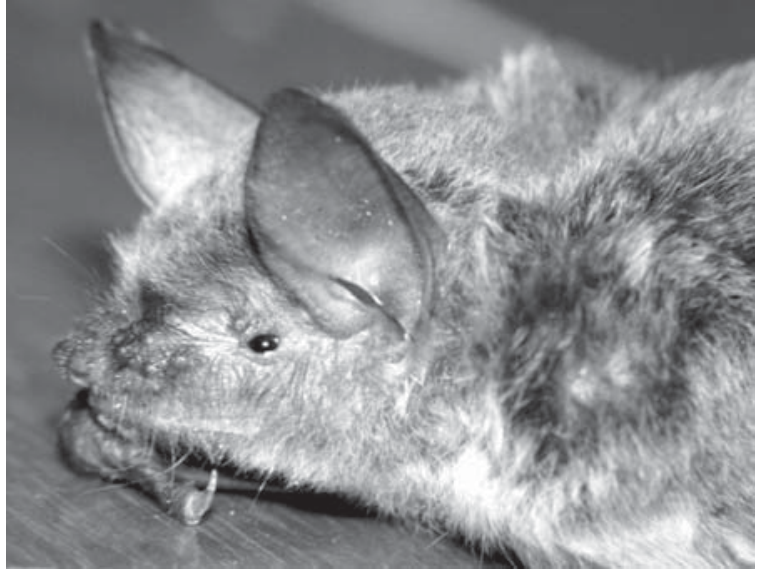

Figure 24. Female Myotis hasseltii (ZMMU S-174724), Stŭng Trêng Province.

Remarks on taxonomy and distribution. This diverse species has a wide distribution. However, Cambodia was only mapped, but not listed by Corbet \& Hill (1992) as a part of this species' range. No records, confirmed by the voucher specimens, except for those by Matveev (1999), are hitherto known for this country.

Around 10 subspecies are currently recognised. The nominate one ranges from north-eastern India and Vietnam to the Lesser Sundas and most of Borneo (Corbet \& Hill, 1992; Koopman, 1994). However, Cambodian specimens presented in this study are conspicuously smaller than those from Nepal - the type locality for Myotis muricola (for measurements see Tate, 1941a and Csorba et al., 1999). Moreover, the recent genetic analysis (Bannikova et al., 2002) demonstrated that Cambodian specimens (material from other parts of Indochina was not available) are very likely to represent a distinct species. The Inter-SINE-PCR-derived genetic distances between Nepalese and Cambodian individuals were as great as between other closely related species of the family Vespertilionidae. From this perspective, more detailed study on a larger sample of bats from different localities would be extremely valuable. Meanwhile, the speculation on subspecific alloca-

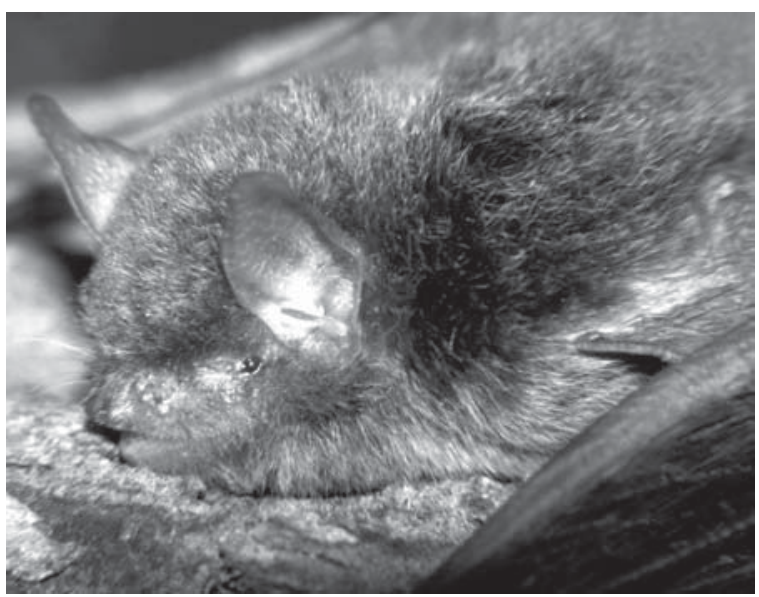

Figure 25. Male Myotis muricola, Kâmpôt Province.

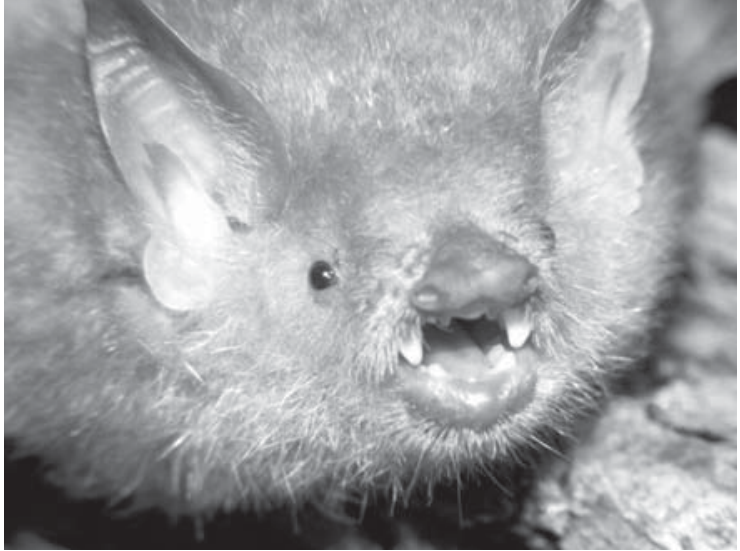

Figure 26. Female Harpiocephalus harpia (ZMMU S168334), Kâmpôt Province.

tion of Indochinese representatives appears to be premature.

Harpiocephalus harpia (Temminck, 1840)

Fig. 26.

Material. Southern extremity of the Elephant Mountains, Kâmpôt Province $\left(10^{\circ} 42^{\prime}-10^{\circ} 35^{\prime} \mathrm{N}, 104^{\circ} 00^{\prime}-104^{\circ} 08^{\prime} \mathrm{E}\right), 27$ January 2000, one adult male (ZMMU S-168333); 28 January 2000, one adult female ('mordax') (ZMMU S-168334).

Remarks on taxonomy and distribution. This is the first record of H. harpia for Cambodia. Tate (1941b) listed six forms of Harpiocephalus, mentioning that mordax is possibly specifically distinct (as proposed by Thomas, 1923, who, in his turn, recognised three 'races' of harpia), and he also suggested that lasyurus (north-eastern India) had to be synonymised with harpia. Koopman (1994) treated lasyurus, with three others, as a subspecies of harpia, allocating the specimens from Thailand and Vietnam among rufulus. Another subspecies, H. h. madrassius Thomas, 1923 from southern India, recognised by Corbet \& Hill (1992), was synonymised with lasyurus by Das (1986).

The above female is Cambodia's first record (confirmed by the voucher specimen) of what used to be known as Harpiocephalus mordax Thomas, 1923, with only few specimens hitherto found in Myanmar, Thailand and Borneo (Corbet \& Hill, 1992).

Harpiocephalus mordax was once considered a subspecies of harpia (Ellerman \& Morrison-Scott, 1951), but since Hill \& Francis (1984) onwards it is widely accepted that it should be regarded as a distinct species. Nevertheless, there is one remarkable circumstance: all known specimens are females.

Das (1986), who did not recognise mordax as a species, examined Indian specimens of $H$. harpia and revealed a wide range of individual variation in size and pelage colour, as well as sexual dimorphism. Nevertheless, Corbet \& Hill (1992) stated that a small series of two males and three females of $H$. harpia from Java, deposited at the $\mathrm{BMNH}$, demonstrates a lesser degree of dimorphism, than the differences in rostral and tooth 
Table 4. Selected external and craniodental measurements of Harpiocephalus specimens, stored at ZMMU and BMNH; ' $\mathrm{n}$ ' (or figures in parentheses) - the number of measured specimens. Data corresponding to the type specimens are typed with bold. Abbreviations are explained in the text.

\begin{tabular}{|c|c|c|c|c|c|c|c|c|c|c|c|c|}
\hline Taxon & $\begin{array}{l}\text { Depositary } \\
\text { number }\end{array}$ & Sex & Locality & $\mathrm{n}$ & $\mathrm{R}$ & CBL & RL & RW & ZW & $\mathrm{C}^{1} \mathrm{M}^{2}$ & $\mathrm{M}^{2} \mathrm{M}^{2}$ & $\mathrm{C}_{1} \mathrm{M}_{3}$ \\
\hline lasyurus & $\begin{array}{l}\text { BMNH } \\
\mathbf{7 9 . 1 1 . 2 1 . 1 1 9}\end{array}$ & $\sigma^{7}$ & India & 1 & 43.7 & - & - & - & - & - & - & - \\
\hline lasyurus & BMNH 16.7.29.42 & $\sigma^{x}$ & Bhutan & 1 & 45.7 & - & 3.91 & 6.22 & - & 6.62 & 7.14 & 7.71 \\
\hline lasyurus & $\begin{array}{l}\text { BMNH } \\
79.11 .21 .118\end{array}$ & q & India & 1 & 49.2 & - & 4.12 & 6.40 & 13.56 & 6.68 & 7.23 & 7.75 \\
\hline madrassius & $\begin{array}{l}\text { BMNH 73.4.16.4, } \\
\text { 23.1.8.1 }\end{array}$ & 우 & India & 2 & $\begin{array}{l}53 \\
(1)\end{array}$ & - & $\begin{array}{l}4.11 \\
(1)\end{array}$ & $\begin{array}{l}6.63 \\
(1)\end{array}$ & $\begin{array}{c}13.86 \\
(1)\end{array}$ & $\begin{array}{c}6.97 \\
(1)\end{array}$ & $\begin{array}{l}6.94 \\
(1)\end{array}$ & $\begin{array}{c}8.17 \\
(1)\end{array}$ \\
\hline $\operatorname{mordax}$ & $\begin{array}{l}\text { BMNH 4.4.27.1, } \\
4.4 .27 .2\end{array}$ & q & Myanmar & 2 & $\begin{array}{c}50.9- \\
54.5\end{array}$ & $\begin{array}{c}20.22- \\
\mathbf{2 1 . 1 1}\end{array}$ & $\begin{array}{l}4.15- \\
4.36\end{array}$ & $\begin{array}{c}7.18 \\
7.21\end{array}$ & $\begin{array}{c}\mathbf{1 4 . 2 2}- \\
14.88\end{array}$ & $\begin{array}{c}7.11- \\
7.24\end{array}$ & $\begin{array}{c}7.63- \\
7.64\end{array}$ & $\begin{array}{r}8.25 \\
8.37\end{array}$ \\
\hline $\operatorname{mordax}$ & BMNH 84.2026 & q & Borneo & 1 & 48.4 & 20.20 & 4.38 & 7.65 & 14.51 & 6.91 & 7.57 & 8.24 \\
\hline $\operatorname{mondax}$ & ZMMU S-168334 & q & Cambodia & 1 & 50.2 & 20.88 & 4.61 & 6.94 & 14.40 & 7.17 & 7.66 & 8.37 \\
\hline harpia & ZMMU S-168333 & $\sigma^{\pi}$ & Cambodia & 1 & 44.4 & 19.12 & 3.80 & 6.30 & 13.11 & 6.55 & 7.04 & 7.62 \\
\hline harpia & $\begin{array}{l}\text { BMNH 7.1.1.484, } \\
9.1 .5 .355, \\
9.1 .5 .356, \\
79.11 .15 .18\end{array}$ & $\sigma^{7}$ & Java & 4 & $\begin{array}{c}45.3- \\
47.4\end{array}$ & $\begin{array}{c}18.37- \\
19.12\end{array}$ & $\begin{array}{c}3.50- \\
3.90\end{array}$ & $\begin{array}{c}6.02- \\
6.14\end{array}$ & $\begin{array}{c}12.35- \\
12.76(3)\end{array}$ & $\begin{array}{c}6.42- \\
6.66\end{array}$ & $\begin{array}{c}6.78- \\
6.88\end{array}$ & $\begin{array}{c}7.25- \\
7.59\end{array}$ \\
\hline harpia & $\begin{array}{l}\text { BMNH 9.1.5.357, } \\
9.1 .5 .358, \\
9.1 .5 .359\end{array}$ & 우 & Java & 3 & $\begin{array}{l}48.9- \\
49.8\end{array}$ & $\begin{array}{c}22.33- \\
22.55\end{array}$ & $\begin{array}{c}3.85- \\
4.04\end{array}$ & $\begin{array}{c}6.46- \\
6.72\end{array}$ & $\begin{array}{c}13.57- \\
13.70\end{array}$ & $\begin{array}{c}6.54- \\
6.76\end{array}$ & $\begin{array}{c}7.02- \\
7.27\end{array}$ & $\begin{array}{c}7.63- \\
7.92\end{array}$ \\
\hline harpia & BMNH 45.9.18.3 & q & Amboina & 1 & 49.4 & - & 3.97 & 6.59 & 13.50 & 6.98 & 7.58 & 8.21 \\
\hline
\end{tabular}

size between harpia and mordax, and therefore proves the latter is a valid species. On this basis they suggest, that three specimens from north-eastern India (remarkably females, too), described by Das, with characteristically expanded zygomatic arches and wide rostra (ZW is $14.4-14.5 \mathrm{~mm}$, and $\mathrm{C}^{1} \mathrm{C}^{1}-6.9-7.1 \mathrm{~mm}$ ), may also pertain to H. mordax (see also Bates \& Harrison, 1997). Eventually, it appears that the above specimens from Java in fact serve as the only justification for the species distinctiveness of mordax. At the same time, their measurements (Tab. 4), including those of two more males from this island, still clearly demonstrate, that the sexual dimorphism in Javanese representatives is as strong as in the rest of available individuals from different localities. Indeed, there is a small overlap between the males and the females from Java in some dimensions, such as rostral length and (to a greater extent) length of the maxillary toothrow, mainly because these are shorter in the females from Java, compared to those from other localities (except Amboina). However, in the rest of the populations the difference between males and females is less pronounced in case of the same dimensions (Tab. 4), too. The forearm in Javanese males is the longest among all studied males, while in the females - the shortest (exceeding only that of one specimen from Borneo, identified as mordax). However, there is still no overlap. Moreover, the condylobasal length is at its maximum in these females (exceeding even that of the type specimen of $\operatorname{mordax}$ ). Hence, we observe the strongest sexual dimorphism among the Javanese specimens in case of this parameter. Both males and females from the island have comparatively narrow zygomatic width, though the difference between the sexes is still great.

Based on the above, we conclude, that the argument by Corbet \& Hill (1992), justifying species distinctiveness of mordax, is not substantiated. Therefore, the whole subspecific composition of Harpiocephalus harpia requires reassessment.

Cambodian male and female, described in this study (the harpia-like and the mordax-like, correspondingly), considerably differ in size (Tabs. $2-4)$ : ZW in the male is $13.11 \mathrm{~mm}$, while in the female $-14.40 \mathrm{~mm}$. The female skull has conspicuously longer rostrum, the front teeth (incisors and canines) are enlarged, and the sagittal crest is better developed, while the braincase is not as convex as in the male. At the same time, no external differences (such as pelage colour) are evident. They purely fit the view of Hill \& Francis (1984) on H. harpia (the male) and H. mordax (the female). However, the recent molecular analysis of Cambodian specimens by means of Inter-SINE-PCR has clearly demonstrated, that they both belong to the same species (Matveev, 2004), which strongly supports the above conclusion on the status of mordax.

In the similar situation, when two Harpiocephalus specimens were recently caught in Phong Nha-Ke Bang Proposed National Park in Vietnam (Timmins et al., 


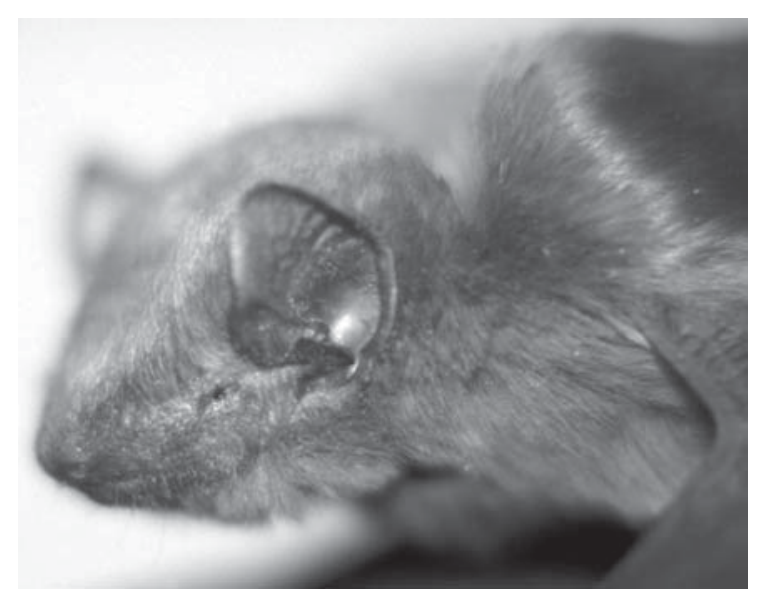

Figure 27. Female Hesperoptenus blanfordi, Kâmpôt Province.

1999), the smaller male was preliminarily identified by P.J.J. Bates as harpia, while the bigger female as mordax. Such repetitive occurrence of male harpia together with female 'mordax' may also prove our views on the status of the latter.

Ecological remarks. Both specimens were caught at the same spot: in the vicinity of the pineapple plantation, above the small manmade pond, surrounded by secondary vegetation.

Hesperoptenus (Milithronycteris) blanfordi (Dobson, 1877)

Fig. 27.

Material. Southern extremity of the Elephant Mountains, Kâmpôt Province $\left(10^{\circ} 42^{\prime}-10^{\circ} 35^{\prime} \mathrm{N}, 104^{\circ} 00^{\prime}-104^{\circ} 08^{\prime} \mathrm{E}\right)$, 29-30 January 2000, one adult male, three adult females, each pregnant with a single foetus (ZMMU S-168300 - S-168303)

Remarks on distribution. Our record is the second for Cambodia. The species was reported previously from the Cardamom Mountains by Hendrichsen et al. (2001). No subspecies. 1851)

Hesperoptenus (Milithronycteris) tickelli (Blyth,

Fig. 28.

Material. Siěmpang and the vicinities, Stŭng Trêng Province $\left(14^{\circ} 06^{\prime}-14^{\circ} 07^{\prime} \mathrm{N}, 106^{\circ} 16^{\prime}-106^{\circ} 23^{\prime} \mathrm{E}\right), 27$ August 2002 one adult female (ZMMU S-174704). $15 \mathrm{~km}$ north of Phum

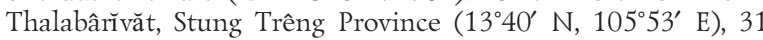
August 2002, one adult male (ZMMU S-174705).

Remarks on taxonomy and distribution. Our record is the second for Cambodia. The species was reported previously from the Cardamom Mountains by Hendrichsen et al. (2001). No subspecies.

\section{Scotophilus heathi Horsfield, 1831}

Fig. 29.

Material. 15 km north of Phumı̌ Thalabârĭvăt, Stŭng Trêng Province $\left(13^{\circ} 40^{\prime} \mathrm{N}, 105^{\circ} 53^{\prime} \mathrm{E}\right), 31$ August 2002, one adult female (ZMMU S-174745).

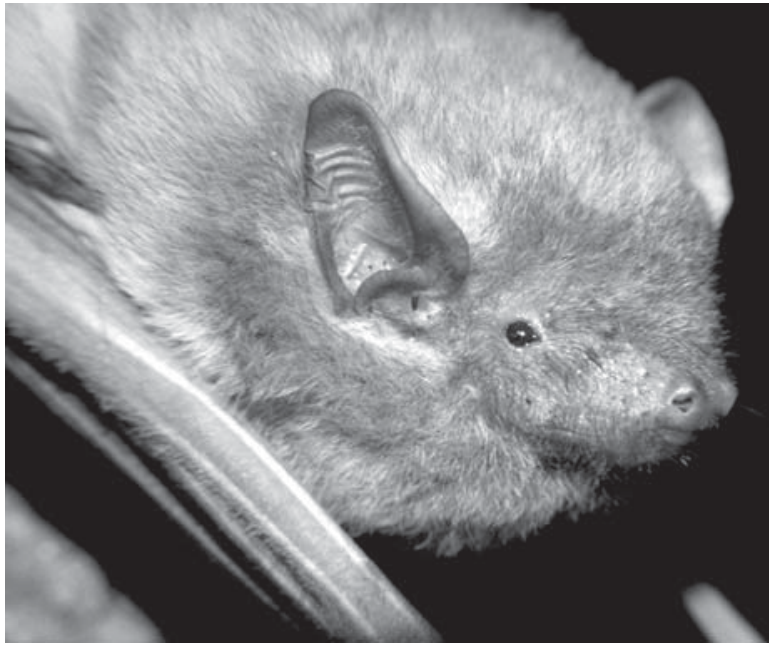

Figure 28. Female Hesperoptenus tickelli (ZMMU S-174704), Stŭng Trêng Province.

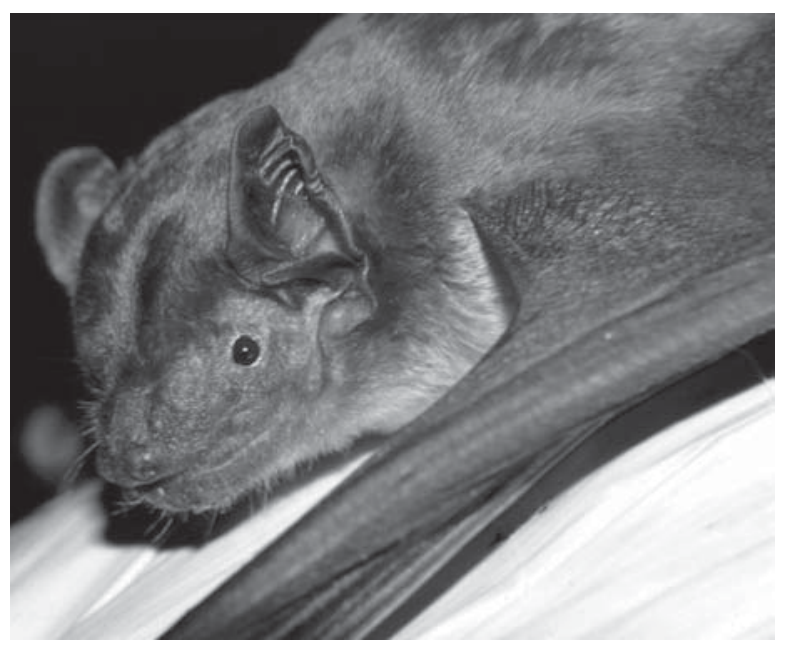

Figure 29. Female Scotophilus heathi (ZMMU S-174745), Stŭng Trêng Province.

Remarks on taxonomy and distribution. This record is the second for the country confirmed by the voucher specimens. $S$. heathi is quite common throughout its range; however Cambodia was only mapped, but not listed as a part of its range by Corbet \& Hill (1992). Our observations show, that it is widely distributed in this country from the south (e.g. Kâmpôt Province) to the north. The species was first recorded in Cambodia by Hendrichsen et al. (2001) in the Cardamom Mountains.

The recognition of subspecies is somewhat preliminary. Thus, Vietnamese populations have not been allocated subspecifically so far. However, Cambodian representatives are extremely similar (both in size and colour) to the specimen from the south of Thailand (ZMMU S-174744), occupied by the form watkinsi (Koopman, 1994), and should likely be referred to the same subspecies. 


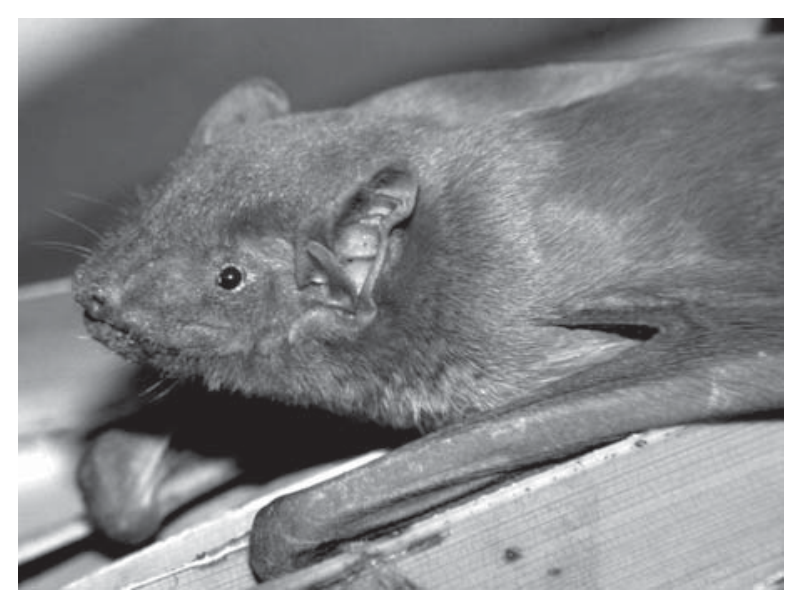

Figure 30. Female Scotophilus kuhlii (ZMMU S-174746), Stŭng Trêng Province.

\section{Scotophilus kuhlii Leach, 1821}

Fig. 30.

Material. Siěmpang and the vicinities, Stŭng Trêng Province $\left(14^{\circ} 06^{\prime}-14^{\circ} 07^{\prime} \mathrm{N}, 106^{\circ} 16^{\prime}-106^{\circ} 23^{\prime} \mathrm{E}\right), 28$ August 2002, one adult female (ZMMU S-174746).

Remarks on taxonomy and distribution. This is the second record of the species for Cambodia confirmed by the voucher specimen. The captured bat is very similar in size and colour to those from southern Thailand (ZMMU S-174747) and Vietnam (Borissenko \& Kruskop, 2003), recognised as S. k. gairdneri Kloss, 1917, and should be referred to the same subspecies.

Miniopterus schreibersii Kuhl, 1819

Fig. 31.

Material. Southern extremity of the Elephant Mountains, Kâmpôt Province $\left(10^{\circ} 42^{\prime}-10^{\circ} 35^{\prime} \mathrm{N}, 104^{\circ} 00^{\prime}-104^{\circ} 08^{\prime} \mathrm{E}\right), 29$ January 2000, 4 February 2000, two adult males (ZMMU S168295 and S-168299)

Remarks on taxonomy and distribution. This is the first record of $M$. schreibersii for Cambodia, confirmed by the voucher specimens. Previously mapped, but not listed for this country by Corbet \& Hill (1992).

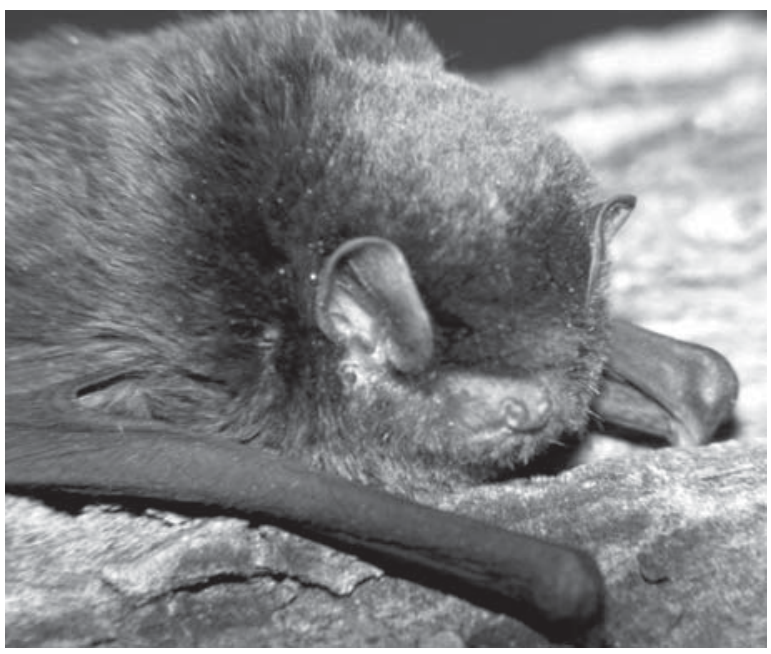

Figure 31. Male Miniopterus schreibersii (ZMMU S-168295), Kâmpôt Province.
The classification of the whole genus is poorly worked out. It is not quite clear how many species comprise it. The recognition of subspecies is hence uncertain as well.

The taxonomy of M. schreibersii - a variable, widely distributed throughout the Old World species remains uncertain. Koopman (1994) recognised $15 \mathrm{sub-}$ species, Corbet \& Hill (1992) listed seven for the Indomalayan region, including parvipes (occurring in southern China and Vietnam) and harardai (Thailand). The subspecific allocation of Cambodian representatives requires additional investigation.

\section{Miniopterus sp.}

Material. Southern extremity of the Elephant Mountains, Kâmpôt Province $\left(10^{\circ} 42^{\prime}-10^{\circ} 35^{\prime} \mathrm{N}, 104^{\circ} 00^{\prime}-104^{\circ} 08^{\prime} \mathrm{E}\right), 29$ January 2000, three adult males (ZMMU S-168296-S-168298).

Remarks on taxonomy and distribution. Specific allocation is not clear. May represents a new species. The above three specimens, collected in Cambodia, could not be assigned with certainty to any Miniopterus species known from the region. In some respects they do resemble $M$. pusillus. However, most of their cranial and dental measurements exceed those known for this species. Some other peculiarities, as shown below, distinguish it from M. pusillus as well.

Dobson (1876) described pusillus as a subspecies of schreibersii, with terra typica in Madras, India. According to him, it resembles the latter in all respects except size (the head and forearm are conspicuously shorter) and distribution of fur, which extends upon the upper surface of interfemoral membrane in pusillus as far as the end of the third caudal vertebra, while in schreibersii - as far as the end of the first one. In australis more than three fourth of the upper surface of interfemoral membrane are covered. Cambodian M. schreibersii and Miniopterus sp. can be easily distinguished by their external, cranial and dental measurements (Tabs. 2 and 3). In addition, ZW in the two specimens of Miniopterus sp. is $7.88-8.08 \mathrm{~mm}$, while in the two $M$. schreibersii $-8.50-8.59 \mathrm{~mm}$; braincase width $-7.74-7.78 \mathrm{~mm}$ and $7.88-7.94 \mathrm{~mm}$, respectively. It is quite noticeable, that regardless to the generally smaller size, all individuals of Miniopterus sp. had longer tibiae, than those of both $M$. schreibersii. The distribution of fur upon interfemoral membrane in schreibersii meets Dobson's description. However, in the examined specimens of Miniopterus sp. it does not extend beyond the end of the second caudal vertebra, and therefore differs from the pattern typical of pusillus. At the same time, the fur is intensely black throughout, as in $M$. pusillus. The status of these specimens is subject to the ongoing analysis, including the molecular investigation.

\section{Discussion}

The first expedition to Cambodia was undertaken by the author in July-August 1998, when only nine species were registered (Matveev, 1999). Two of them were recorded there for the first time (their occurrence was confirmed by the voucher specimens): Cynopterus brachyotis and Myotis muricola. Two others, namely 
Pteropus hypomelanus and Megaderma spasma, were mentioned with a question mark, and their occurrence in Cambodia was confirmed in the course of the later expeditions. One species, Taphozous longimanus, was misidentified as Saccolaimus saccolaimus, and hence the presence of the latter in Cambodia is rejected here. However, its occurrence in the country is possible from the point of recent records from Vietnam, in immediate proximity to Cambodian border.

In the course of the author's further expeditions in January-February 2000 and July-September 2002 eight more species, new to Cambodian bat fauna, were found in the country. These are Macroglossus sobrinus, Taphozous theobaldi, Hipposideros cineraceus, H. galeritus, Rhinolophus pusillus, Miniopterus pusillus, Miniopterus sp., and Harpiocephalus harpia (including H. mordax, which was proved to be a synonym of harpia). Occurrence of Rousettus leschenaulti and Pteropus hypomelanus was confirmed by the voucher specimen and photographs, respectively. Therefore, this study expands the list of Cambodian bat species to 48 , including one species of long-fingered bats, Miniopterus sp., which may represent a new species (the matter of ongoing research). Occurrence of two species from the list, namely Cynopterus horsfieldii and Megaerops ecaudatus, is still questionable and needs more reliable data.

The latest field investigations undertaken in Cambodia provide essential information on bat fauna of this part of Indochina. However, some parts of the country, such as its centre, east and north, remain almost completely unexplored. In this view, separate investigations to assess the bat fauna of these areas and to determine the conservation status of individual species is needed, for more and more territories are now turned over for economic operation.

The Kingdom of Cambodia is situated close to the geographic centre of the Indomalayan Region. Forty percent of its known bat fauna is predominantly formed by the species more or less widely distributed throughout the region, but not spreading outside. These are Cynopterus sphinx, C. brachyotis, Eonycteris spelaea, Macroglossus sobrinus, Taphozous longimanus, T. melanopogon, T. theobaldi, Megaderma spasma, Rhinolophus luctus, Hipposideros galeritus, H. larvatus, Myotis hasseltii, Tylonycteris pachypus, T. robustula, Scotophilus kuhlii, Hesperoptenus tickelli, Harpiocephalus harpia, Kerivoula papillosa, and Chaerephon plicata. Several others, being of the Indomalayan origin, marginally occur in the Palaearctic: Rousettus leschenaulti, Megaderma lyra, Hipposideros cineraceus (Cambodian record extends the species' range deep into Indochina, being the southernmost point of its distribution in there), H. pomona, Rhinolophus pusillus, Myotis muricola, and Kerivoula hardwickii, or Australasia: Pteropus hypomelanus. Only the range of Pipistrellus tenuis extends outside Indomalaya both to the Palaearctic and simultaneously quite far to the Australasia (occurrence of Myotis muricola in the second region is possible, but not proven).

One polymorphic species, Miniopterus schreibersii, found in Cambodia, is widespread throughout the Old World, Australia and Oceania.
Lesser number of species, known at present from Cambodia and spreading either to the Palaearctic or Australasia, have more limited distribution within the Indomalayan region itself. Some of them have wider range in the continental part of the region. These are Hipposideros armiger and Pipistrellus coromandra (both marginally occur in the Palaearctic), Scotophilus heathi. In case of $P$. coromandra Cambodian record is the extreme south-eastern point of its distribution in Indochina. Other species are more or less confined to the islands of Indomalaya: Rousettus amplexicaudatus and Macroglossus minimus. Cambodia here, on contrary, lies close to the north-western boundaries of both species' ranges.

The rest of species, which make together more than one quarter of Cambodia's known bat fauna, do not occur outside the Indomalayan Region and are either characterised by limited distribution within it, and/or by limited number of records as a whole. One of these, Myotis rosseti, is confined to Indochinese Subregion only. Others are also known from elsewhere in the region: Pteropus lylei, Cynopterus horsfieldii, Megaerops ecaudatus (occurrence of the latter two in Cambodia is not evident), Megaerops niphanae, Rhinolophus acuminatus, Rh. borneensis, Rh. malayanus, $R h$. shameli, Arielulus circumdatus, Hesperoptenus blanfordi, Myotis annectans (Cambodia is extreme southeastern part of its range) and Otomops wroughtoni. The latter till recently was known from southern India only. Cambodian records prove it is much wider distributed in the region.

No endemics are known (the status of Miniopterus $\mathrm{sp}$. is a subject to additional analysis), though a number of species reported for this country are rare as a whole.

Despite the fact that quite a few Indomalayan bat species known from Cambodia are also known from the neighbouring zoogeographic regions as, none of truly Palaearctic or Australian taxa have been recorded in the country so far, not counting Miniopterus schreibersii, with its wide distribution. In this regard, Cambodian bat fauna could be characterised as typical Indomalayan, with ca. $70 \%$ of its known species not occurring outside the region.

ACKNOWLEDGEMENTS. The author would like to express his gratitude to the directorate of Joint Russian-Vietnamese Science and Technology Research Centre, especially Dr. Yuri Prischepo, for their incredible help. I thank Nikolay Doroshenko for all his support and readiness to assist with what ever was needed. I appreciate the organisational aid and useful advices of Alexander Andrianov and especially Oleg Shumakov, who also provided the photographs and video materials on Rhinolophus luctus. In particular, I would like to thank Dr. Anna Vassilieva (Faculty of Biology, Moscow State University) for her patience and incredible support during our teamwork in Cambodia in 2000. I thank Dr. Paulina Jenkins and Daphne Hills for the permit to carry out a comparative research in the Natural History Museum, London, and all their incredible support and understanding. I am grateful to Dr. David Harrison and Dr. Paul Bates (Harrison Zoological Museum, Sevenoaks, UK) for allowing me to examine some Miniopterus specimens from their collection, to Mr. Malcolm Pearch from the same institution for his assistance during my travel to Sevenoaks. I would also like to thank Dr. Dmitry Musolin for his infotainment. 


\section{References}

Andersen K. 1912. Catalogue of the Chiroptera in the Collection of the British Museum. Vol. 1. Megachiroptera. Second Edition. London: British Museum (Natural History). $854 \mathrm{p}$.

Andersen K. 1918. Diagnoses of new bats of the families Rhinolophidae and Megadermatidae // Annals and Magazine of Natural History, Series 9. Vol.2. P.347-384.

Bannikova A.A., Matveev V.A. \& Kramerov D.A. 2002. Using Inter-SINE PCR to study mammalian phylogeny // Russian Journal of Genetics. Vol.38. No.6. P.714-724.

Bates P.J.J. \& Harrison D.L. 1997. Bats of the Indian Subcontinent. Sevenoaks, UK: Harrison Zoological Museum Publications. $258 \mathrm{p}$.

Bates P.J.J., New T., Pearch M.J., Maung Swe K., Hla Bu S.S. \& Tun T. 2000. A review of bat research in Myanmar (Burma) and results of a recent survey // Acta Chiropterologica. Vol.2. No.1. P.53-82.

Bergmans W. \& Rozendaal F.G. 1988. Notes on collections of fruit bats from Sulawesi and some off-lying islands (Mammalia: Megachiroptera) // Zoologische Verhand. No.248. P.1-74.

Borissenko A.V. 1999. A mobile trap for capturing flying bats // Plecotus et al. No.2. P.10-19.

Borissenko A.V. \& Kruskop S.V. 2003. Bats of Vietnam and Adjacent Territories. An Identification Manual. Moscow: Geos. 201 p.

Corbet G.B. \& Hill J.E. 1992. The Mammals of the Indomalayan Region. Oxford: Oxford University Press. 488 p.

Csorba G., Kruskop S.V. \& Borissenko A.V. 1999. Recent records of bats (Chiroptera) from Nepal, with remarks on their natural history // Mammalia. T.63. No.1. P.61-78.

Csorba G., Ujhelyi P. \& Thomas N. 2003. Horseshoe bats of the World (Chiroptera: Rhinolophidae). Bishop's Castle, UK: Alana Books. 160 p.

Das P.K. 1986. Taxonomic status of Harpiocephalus harpia madrassius Thomas, 1923 (Chiroptera: Vespertilionidae) with comments on other described forms under the genus Harpiocephalus Gray, 1842 // Journal of Bombay Natural History Society. Vol.83. No.2. P.311-316.

Dobson G.E. 1876. Monograph of the Asiatic Chiroptera and Catalogue of the Species of Bats in the Collection of the Indian Museum, Calcutta. London: Taylor \& Francis. viii+228 p.

Dobson G.E. 1880. Report on accessions to our knowledge of the Chiroptera during the past two years (1878-80) // Report of the fiftieth Meetings of the British Association for the Advancement of Science. P.169-197.

Ellerman J.R. \& Morrison-Scott T.C.S. 1951. Checklist of Palaearctic and Indian Mammals 1758 to 1946. London: Trustees of the British Museum (Natural History). 810 p.

Heaney L.R., Gonzales P.C. \& Alcala A.C. 1987. An annotated checklist of the taxonomic and conservation status of land mammals in the Philippines // Silliman Journal. Vol.34. No.1-4. P.32-66.

Hendrichsen D.K., Bates P.J.J. \& Hayes B.D. 2001. Recent records of bats (Chiroptera) from Cambodia // Acta Chiropterologica. Vol.3. No.1. P.21-32.

Hill J.E. 1983. Bats (Mammalia: Chiroptera) from IndoAustralia // Bulletin of the British Museum (Natural History): Zoology. Vol.45. No.3. P.103-208.

Hill J.E. \& Thonglongya K. 1972. Bats from Thailand and Cambodia // Bulletin of the British Museum (Natural History): Zoology. Vol.22. No.6. P.171-196.

Hill J.E. \& Francis C.M. 1984. New bats (Mammalia: Chiroptera) and new records of bats from Borneo and Malaya // Bulletin of the British Museum (Natural History): Zoology. Vol.47. No.5. P.305-329.
Hill J.E., Zubaid A. \& Davison G.W.H. 1986. The taxonomy of leaf-nosed bats of the Hipposideros bicolor group (Chiroptera: Hipposideridae) from southeastern Asia // Mammalia. T.50. No.4. P.535-540.

Huynh Dang Huy, Dao Van Tien, Cao Van Sung, Pham Trong Anh \& Hoang Minh Khien. 1994. [Checklist of Mammals in Vietnam]. Hanoi: Science and Technics. 168 p. [in Vietnamese].

Khajuria H. 1979. Taxonomical and ecological studies on bats of Jabalpur District Madhya Pradesh, India. Part 1. (Families Pteropidae, Rhinopomatidae and Emballonuridae) // Records of the Zoological Survey of India. Occasional paper 13. P.1-59.

Klein J.M. 1969. Cimex angkorae n. sp., une nouvelle punaise du Cambodge // Bulletine de la Société Entomologique de France. T.74. P.139-145.

Klein J.M. 1971. La faune des puces du Cambodge (Siphonaptera) // Cahier ORSTOM (Serie Entomologie Médicale et Parasitologie). T.9. P.223-238.

Kock D. 2000. On some bats (Chiroptera) from southern Cambodia with a preliminary checklist // Zeitschrift für Säugetierkunde. Bd.65. Hf.4. P.199-208.

Koopman K.F. 1989. Distributional patterns of Indo-Malayan bats (Mammalia: Chiroptera) // American Museum Novitates. No.2942. P.1-19.

Koopman K.F. 1994. Chiroptera: Systematics. Handbook of Zoology. Mammalia, Part 60. Berlin: Walter de Gruyter. 217 p.

Matveev V.A. 1999. New records of bats from Cambodia // Plecotus et al. No.2. P.129-130.

Matveev V.A. 2004. [Systematics of Old World Chiroptera derived from the insertions of DNA interspersed repeats]. PhD thesis. Moscow: Moscow State University. 293 p. [in Russian].

Medway Lord. 1978. The Wild Mammals of Malaya (Peninsular Malaysia) and Singapore. Second Edition. Kuala Lumpur: Oxford University Press. 127 p.

Mickleburgh S.P., Hutson A.M. \& Racey P.A. 1992. Old World Fruit Bats: An Action Plan for Their Conservation. IUCN, Gland, Switzerland: IUCN/SSC Chiroptera Specialist Group. viii+252 p.

Phillips C.J. 1967. A collection of bats from Laos // Journal of Mammalogy. Vol.48. No.4. P.633-636.

Rookmaaker L.C. \& Bergmans W. 1981. Taxonomy and geography of Rousettus amplexicaudatus (Geoffroy, 1810) with comparative notes on sympatric congeners (Mammalia, Megachiroptera) // Beaufortia. Vol.31. No.1. P.1-29.

Shamel H.H. 1942. A collection of bats from Thailand (Siam) // Journal of Mammalogy. Vol.23. No.3. P.317-328.

Tate G.H.H. 1941a. Results of the Archbold expeditions. No. 39. Review of Myotis of Eurasia // Bulletin of the American Museum of Natural History. Vol.78. Art.8. P.537-565.

Tate G.H.H. 1941b. Results of the Archbold expeditions. No. 40. Notes on vespertilionid bats // Bulletin of the American Museum of Natural History. Vol.78. Art.9. P.567-597.

Thomas O. 1923. On the forms contained in the genus Harpiocephalus // Journal of Bombay Natural History Society. Vol.29. P.88-89.

Timmins R.J., Do Tuoc, Trinh Viet Cuong \& Hendrichsen D.K. 1999. A preliminary assessment of the conservation importance and conservation priorities of the Fong NhaKe Bang Proposed National Park, Quang Binh Province, Vietnam. Hanoi: Flora and Fauna International - Indochina Programme. [unpublished report].

Trouessart E.-L. 1897. Catalogus mammalium tam viventium quam fossilium. Nova Editio (Prima completa). Fasciculus I. Primates, Prosimiae, Chiroptera, Insectivora. Berlin: R. Friedländer \& Sohn. 664 p.

Walston J. \& Bates P.J.J. 2001. The discovery of Wroughton's free-tailed bat Otomops wroughtoni (Chiroptera: Molossidae) in Cambodia // Acta Chiropterologica. Vol.3. No.2. P.249-252. 